\title{
UNDERSTANDING THE RESOURCE IMPACT USING MATCHING
}

\author{
Ilkin Aliyev
}
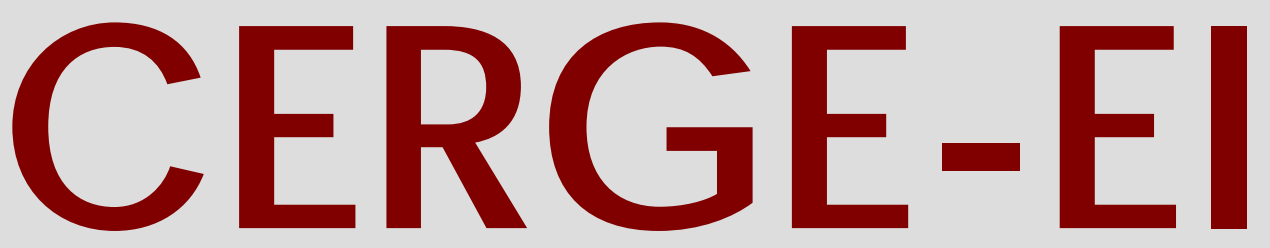

Charles University CenterforEconomic Research and Graduate Education Academy of Sciences of the Czech Republic Economic s Institute 


\section{Working Paper Series 451 (ISSN 1211-3298)}

\section{Understanding the Resource Impact Using Matching}

Ilkin Aliyev

CERGE-EI

Prague, October 2011 
ISBN 978-80-7343-254-6 (Univerzita Karlova. Centrum pro ekonomický výzkum a doktorské studium)

ISBN 978-80-7344-246-0 (Národohospodářský ústav AV ČR, v.v.i.) 


\title{
UNDERSTANDING THE RESOURCE IMPACT USING MATCHING*
}

\author{
Ilkin Aliyev \\ CERGE-EI $^{\S}$
}

\begin{abstract}
We investigate the resource impact on economic growth using matching. Using a nonparametric minimum-distance matching method, we match the countries according to their observable characteristics, and estimate the relative growth rates of each matched pair. This way we are able to analyze the impact of the resources on relative growth rates, rather than on absolute growth rates as it has been done in the literature. Assuming correlation between observables and unobservables, the matching based on observables may control for unobservables as well. If this assumption is satisfied, matching allows us to control for more variables and to single out the direct effect of the resource abundance variable. We use different measures of resource abundance to check the robustness of such a relationship. The empirical results suggest that there is a strong negative relationship between relative exhaustible resource abundance and relative economic growth. For nonexhaustible resources, the results are mixed, with often a positive impact on relative growth. We discuss the contrary evidence in Sala-i-Martin et al. (2004) and highlight the differences in methodology and estimation that potentially may create differences in the results.
\end{abstract}

Keywords: resource-rich countries, minimum-distance matching, relative GDP growth, relative resource richness impact, omitted variable bias

JEL Classification: C14, O11, O13, O47, Q32

\footnotetext{
*I am very grateful to Peter Katuscak and Jan Kmenta for their valuable comments. I would like to thank Byeongju Jeong and Evangelia Vourvachaki for their helpful comments and constant support. I also thank Laura Strakova for editing the paper and Bozena Bobkova for translating the abstract into the Czech language. All errors remaining in this text are the responsibility of the author.

${ }^{\S}$ CERGE-EI is a joint workplace of the Center for Economic Research and Graduate Education, Charles University, and the Economics Institute of the Academy of Sciences of the Czech Republic.

Address: CERGE-EI, P.O. Box 882, Politických vězňů 7, Prague 1, 111 21, Czech Republic

ilkin.aliyev@cerge-ei.cz

The work was supported by the grant SVV-2011-263 801.
} 


\begin{abstract}
Abstrakt
Tento článek zkoumá vliv přírodních zdrojů na ekonomický růst $\mathrm{s}$ použitím ekonometrické metody matchingu. Používáme metodu neparametrického matchingu minimálních vzdáleností tak, že dochází ke spárování zemí na základě jejich pozorovatelných charakteristik a následnému odhadu relativní míry růstu každého přičleněného páru. Tento způsob nám umožní analyzovat vliv přírodních zdrojů na relativní růst, zatímco současná literatura je v tomto ohledu omezena na růst absolutní. Budeme-li předpokládat korelaci mezi pozorovatelnými a nepozorovatelnými charakteristikami, pak právě analýza na základě metody matchingu založená na pozorovatelných charakteristikách je schopna ohlídat také působení nepozorovatelných charakteristik. Při splnění tohoto předpokladu matching umožňuje ohlídat větší množství proměnných a zároveň vyjádřit přímý efekt proměnné hojnosti prrírodních zdrojů. V článku používáme různé míry hojnosti přírodních zdrojů, abychom otestovali robustnost takového vztahu. Empirické výsledky ukazují, že zde existuje silný negativní vztah mezi hojností vyčerpatelných prrírodních zdrojů a relativním ekonomickým růstem. Výsledek pro nevyčerpatelné zdroje je spíše smíšený s často pozitivním vlivem na ekonomický růst. Věnujeme se i rozdílnosti výsledků článku Sala-i-Martin et al. (2004), která je pravděpodobně způsobená odlišnou metodologií odhadu.
\end{abstract}




\section{Introduction}

Much research has been done on whether a natural resource boom leads to higher economic growth and a wealthier nation, or whether it is some kind of curse which in the longrun slows down the overall economic development of a resource-rich country (as described in Stevens 2003). In the series of papers by Sachs and Warner (1995, 1997, 1999, and 2001), it is argued that there is a strong negative link between resource abundance and economic growth at a cross-country level. Following their work, different authors have tried to understand and explain this phenomenon. Interestingly, the majority of the empirical work supports a negative relationship between resource abundance and economic growth (Sachs and Warner 1995, 1997, 1999, 2001; Auty 2001a; Gylfason et al. 1999).

Along with the supporters of the resource curse phenomenon, there is much literature that argues against it. In most of the cases, these critiques are similar to those made for general cross-country growth regressions. Manzano and Rigobon (2001), and Lederman and Maloney (2002) point out econometric issues related to such cross-country regressions. The main concerns are the omitted variable bias and the endogeneity problem. Using fixed-effect estimation which accounts for these issues they find that the impact of resources on growth is not statistically significant. However, the resource abundance measure is relatively time invariant, and differencing in fixed-effect estimation may decrease the variance of the resource variable which may lead to an increase in the variance of the estimator.

In this research, we also analyze the resource impact on economic growth. Unlike the previous literature on the subject, we focus on the relative growth rates rather than on the absolute growth rates of resource-rich countries. For every country we try to find similarmatched countries according to their observable characteristics, and estimate the relative 
growth rates for every matched pair of countries. Then, we estimate the impact of the relative resource richness on the relative growth rates, but not on absolute growth rates as has been done in the literature. This will allow us to estimate the under- or overperformance of the country depending on how relatively resource abundant it is. Matching has an advantage over fixed-effect estimation, as differencing is performed between countries, but not according to time.

One of the main challenges here is to find a match for each resource-rich country. Here, we use minimum vector distance matching (exact matching) shown in Dehejia and Wahba (2002). This simple method of matching two countries is based on minimized distance between the vectors of variables of these countries. In other words, the smaller the distance between the two vectors is, the more similar the countries are.

Contrary to the findings of the previous resource curse literature, Sala-i-Martin, Doppelhofer and Miller (2004) identify the fraction of GDP in mining among the 18 most robust variables affecting growth, and conclude that it has a positive impact on growth. They show that with more control variables included into the regression, the more significant is the resource impact on growth. This means that the mining variable requires other conditioning variables to show its full impact. In our research, assuming correlation between observables and unobservables, the matching based on observables may control for unobservables as well. If this assumption is satisfied, matching allows us to control for more variables and to single out the direct effect of the resource abundance variable. Also, we plan to use different measures of resource abundance.

\section{The Debate in the Literature}

The series of papers by Sachs and Warner (1995, 1997, 1999, and 2001) have drawn attention to the empirical analysis of the link between resource abundance and economic 
growth. The most distinctive feature of Sachs and Warner's (henceforth, SW) work is empirical evidence for the robust negative relationship between resources and growth using an econometric approach. They name this phenomenon the "Resource Curse". The existence of such "unexpected" empirical evidence has been a motivation for the literature.

Sachs and Warner estimate a cross-country regression equation showing that per capita GDP growth negatively depends on resource abundance during the period of 1960-1990. As the measure of resource abundance, they use the share of primary exports to GDP. They argue that the negative link stays significant after controlling for different variables found in earlier growth literature. ${ }^{1}$

Also, SW claim that the results are robust to the different measures of resource abundance and to the outliers. Three alternative measures of resource abundance are considered: 1) the share of mineral production in GDP; 2) the fraction of primary exports in total exports; and 3) the log of land area per person. Despite differences in the measures of resource abundance, its impact on growth remains negative and statistically significant. As each observation has the same weight in regressions, SW exclude those observations that have high residuals to decrease the sensitivity of the results to a few observations.

Inspired by SW's work, the literature became focused on using econometric techniques to explain such an adverse effect of resources on growth. ${ }^{2}$ Among others, Gylfason, Herbertson and Zoega (1999) also analyze the relationship between growth and the size and volatility of the primary sector. They suggest an alternative measure of resource abundance additional to that used by SW. Gylfason et al. (1999) test the primary sector labor share as a resource abundance measure and find evidence suggesting the existence of the resource curse. The evidence clearly supports the results of SW.

\footnotetext{
1 SW use variables from Barro (1991), DeLong and Summers (1991), King and Levine (1993), Mankiw, Romer and Weil (1992).

${ }^{2}$ Stevens (2003) provides an extensive literature review on the subject.
} 
There is much literature that argue against the results of SW work and the existence of the resource curse phenomenon. Most of these critiques are concentrated on the estimation methodology of the cross-country regressions used in SW. Namely, omitted variable bias and endogeneity issues are crucial ones that need to be addressed when estimating crosscountry regressions.

Manzano and Rigobon (2001) re-estimate SW's regressions using panel data. As they find similar results as in SW's work, indicating a negative association between growth and resource abundance with panel data too, they point out a possible bias due to omitted variables and suggest using fixed-effect estimation. The fixed-effect estimation eliminates the robustness of the resource abundance variable. This result allows them to conclude that there is significant omitted variable bias which has been taken into account in the fixedeffect estimation. Manzano and Rigobon state that over the last 30 years production in the resource sector has been declining and suggest focusing on the performance of nonresource GDP instead of total GDP, as the latter is directly linked to the resource sector itself. The use of non-resource GDP does not change the results significantly compared to the total GDP in the sense that the negative link is still present in cross-sectional and panel data estimation but loses its significance once fixed-effect estimation is applied.

Lederman and Maloney (2002) are also aware of potential econometric issues related to SW's regressions. They challenge the sensitivity of the results in three ways: 1) using different time periods; 2) the presence of omitted variable bias using fixed-effect estimation; 3) the presence of reverse causality. They show the negative effect of natural resource exports on growth only for the period between 1950 and 1989. However, using the data from Maddison (1994), they obtain a positive effect of resource abundance for the periods $1820-1873$ and 1913-1950, although their results are not statistically significant. Therefore, they claim that SW's results do not survive the test of time. Similar to Manzano 
and Rigobon (2001), they find important bias and inconsistency problems due to omitted country-specific variables. Here, after using fixed-effect estimation, the natural resource abundance variable effect on GDP is not statistically significant and sometimes has a positive sign.

Besides the econometric concerns of SW's work, there are other authors who draw attention to the proper identification of the resource abundance variable, such as Stijns (2001), Ding and Field (2005), and Cerny and Filer (2007). They suggest the differentiation of two key aspects of the resource-abundant country regarding natural resources: natural resource dependence and natural resource endowment. Here, the general argument is that although natural resource dependence retards growth, natural resource endowment is positively related to growth.

Ding and Field (2005) obtain similar results when replicating the growth regressions with natural resource abundance variables that were used previously by SW and other authors. If natural resource capital per capita is used as a resource abundance measure then its effect on growth appears to be positive. However, they also estimate a recursive model to account for possible endogeneity between natural capital and growth. Doing so, they find that its effect on growth is statistically insignificant. Cerny and Filer (2007) achieves similar results. Namely, when the natural resource endowment measure is used instead of the natural dependence measure, its impact on growth becomes insignificant. This result leads them to claim that there is no such phenomenon as the resource curse.

Contrary to the findings of the previous resource curse literature, Sala-i-Martin, Doppelhofer and Miller (2004) identify the fraction of GDP in mining among the 18 most robust variables affecting growth, and find that it has a positive impact on growth. They use a novel methodology, Bayesian Averaging of Classical Estimates, to evaluate the robustness of growth regression variables. The authors acknowledge that this result is in 
contrast to what was obtained in the resource curse literature. They show that with more control variables included into the regression, the more significant is the resource impact on growth. According to Sala-i-Martin et al. (2004), mining requires other conditioning variables to show its full impact.

Our research contributes to the literature by applying a novel methodology - matching - that could account for the omitted variable issue in the regression. Different from the fixed-effect estimation in the literature, matching does not reduce the variance of the resource abundance measure. By matching similar countries we are able to control for unobservables. Increase in the controls of unobservables may lead to results similar to Sala-i-Martin et al. (2004), that is, that resource abundance has a positive effect on growth. Matching enables us not only to account for omitted variable bias, but also underlines the effect of resource abundance by putting more weight on similar countries.

\section{Methodology}

We employ a simple method of matching based on minimized distance between $\mathrm{X}$ vector of covariates. In other words, the smaller the distance between covariate vectors, the more similar the countries. The vector distance $\mathrm{S}$ between $X_{i}=\left(x_{i}^{1}, \ldots, x_{i}^{N}\right)$ for country $i$ and $X_{j}=\left(x_{j}^{1}, \ldots, x_{j}^{N}\right)$ for country $j$ is computed as:

$$
S_{i j}=\sqrt{\left(x_{i}^{1}-x_{j}^{1}\right)^{2}+\ldots\left(x_{i}^{N}-x_{j}^{N}\right)^{2}}
$$

where $\mathrm{N}-$ is the number of variables (covariates) used to match the countries.

We define a threshold value for the distance measure $\bar{S}$. Two countries that have a distance below $\bar{S}$ are considered to be similar. There might be more than one country that 
is less than $\bar{S}$ distance from the country under consideration. The relative growth rates of country $i$ with respect to country $j$ are obtained as follows:

$\widetilde{Y}_{i j}=Y_{i}-Y_{j}$ for all $j$ 's where $S_{i j} \in[0, \bar{S}]$

It is worth noting that in (2) all countries within this distance are weighted equally in computing the relative growth rates. However, potentially we could use weighting of the observations based on their closeness to the country under consideration.

The literature on resource impact on growth considers the following general form of the regression:

$Y_{i t}=\delta_{0}+X_{i t}^{\prime} \beta+\alpha R_{i t}+\eta_{i}+\varepsilon_{i t}$

where $Y_{i t}$ is per capita GDP growth rate of country $i$ at time $t, R_{i t}$ is the resource abundance variable for the country $i$ at period $t, X_{i t}$ represents all other variables that affect growth, $\eta_{i}$ represents country-specific constant characteristics not captured in the estimation, $\delta_{0}$ is a constant, and $\varepsilon_{i t}$ is an error term.

As already mentioned, the simple OLS estimation of (3) may suffer from omitted variable bias. The omitted variable bias issue may be solved using fixed-effect estimation as is done by Manzano and Rigobon (2001) and Lederman and Maloney (2002). The fixed-effect estimation requires panel data with a minimum of two time periods. Differencing with respect to time accounts for country-specific unobservables, which is the potential cause for the bias. 
Of major interest in the resource impact literature is the effect of the variable $R_{i t}$ on growth. Potentially, this variable can be dichotomous, taking a unit value when the country is resource rich. However, in this case, a binary resource variable will not allow for the fixed-effect of estimation to be performed in order to eliminate the effect of the omitted variables, because differencing with respect to time will also eliminate any identifying variation in the binary resource variable.

In the literature, usually $R_{i t}$ is not a "dummy". As noted above, the most often used measures of resource abundance are natural resource exports share and natural resource production share. In this case, differencing will not eliminate the identifying variation in the resource variable because it may change with time. However, the potential issue is the low variance of this variable across time for a resource-rich country. The resource-rich country may not have changes in its resource abundance if the time is more frequent. And differencing with respect to time may lead to an increase in the variance of the estimate $\hat{\alpha}$, which will make it difficult to draw inferences regarding resource impact. We conjecture that this is one of the reasons that make the results of Manzano and Rigobon (2001) and Lederman and Maloney (2002) regarding the resource abundance variable statistically insignificant.

In this research, the main purpose of applying the matching procedure is to identify comparable countries. Using successful matching procedures will decrease the possibility of wrongly matched pairs. The objective is to make sure that the best matches are obtained. After identifying the right matches, we proceed with estimating the effect of resource abundance on countries' relative growth performance.

Here, the variable of interest will be the relative growth rates of a country with respect to similar countries computed as in (2), instead of the traditional absolute growth rate used in most of the growth regression literature. The use of relative growth rates will allow us 
to account for the issue of omitted variable bias in SW's regressions. In other words, if matching is performed based on observed country-specific characteristics, then similarity of the matched pair may account for unobserved country-specific characteristics that cannot be included into the regression due to short samples and non-availability issues. In this case, the relative growth rates will not contain those unobservables because they have been differenced out. This is one of the possible solutions to the omitted variable bias.

In this regard, matching possesses an advantage over fixed-effect estimation because the differencing is not performed with respect to time. Instead, by matching a resourcerich country with a resource-poor country, we underline the effect of the resources and at the same time eliminate the effect of the omitted country-specific variables. When countries are matched based on $\mathrm{X}$, to account for omitted country-specific factors $\eta_{i}$, we presume that the population correlation is non-zero, $\operatorname{corr}\left[X_{i t}, \eta_{i}\right] \neq 0$. If the opposite is true, then matching based on X's cannot eliminate the omitted variable bias. If the correlation is significant, then we are able to account for more variables.

After computing relative growth rates on matched countries, we will proceed with the estimation of the effect of $R_{i t}$ on those growth rates. Here, we estimate a simple linear regression model using relative resource richness as the only explanatory variable:

$$
\widetilde{Y}_{i j t}=\widetilde{\eta}_{i j}+\widetilde{\alpha} \widetilde{R}_{i j t}+\widetilde{\varepsilon}_{i t}
$$

where, $\widetilde{Y}_{i j t}=Y_{i t}-Y_{j t}, \widetilde{R}_{i j t}=R_{i t}-R_{j t}$ and $\widetilde{\eta}_{i j}=\eta_{i}-\eta_{j}$

Different from (3), the above regression does not contain $X_{i t}$ and $\eta_{i}$. Instead, these factors are used to identify the best matches. If matching is successful, then matching allows us to account for more control variables and omitted variables. If $\mathrm{X}$ is highly 
multidimensional, that makes it practically impossible to include them all into the regression as explanatory variables. On the contrary, matching based on multidimensional $\mathrm{X}$ allows us to control for them without including them into the regression.

\section{Empirical results}

\subsection{Cross-country evidence}

The initial step is to match all countries. In other words, we try to find matches for every country. We use exact matching using the dataset in Sala-i-Martin et al. (2004). By running many growth regressions with different explanatory variables, Sala-i-Martin et al. (2004) show that there are 18 variables that are robustly related to growth; the mining fraction of GDP is among those variables. We select those variables to match the countries. However, we exclude the mining fraction of GDP-resource abundance variable, because in our case, resource abundance is our focus variable and we would like to match countries with different resource abundance levels to see the impact of resource richness. Therefore, we have 17 variables to use for matching. Table 1 shows the list of variables used for matching. ${ }^{3}$

Before implementing the minimum vector distance matching technique, we divide each variable by its standard deviation. As each of these variables has a different scale, applying such normalization would eliminate differences in scale. After normalization, we pick a country and find the distance with each and every country. The smaller the vector distance is, the more similar the countries are.

We should note that we cannot find two countries with exactly the same values of $\mathrm{X}$ covariates. This is because we have a limited number of countries. Therefore, we are only able to find the distance value closest to zero. We choose the threshold value for distance

\footnotetext{
${ }^{3}$ Please note that all the tables and graphs are at the end of the paper.
} 
0.1 ; that is, if the distance is less than 0.1 then the countries are similar. Applying such a threshold yields a different number of matches for different countries. In total, we found 390 cross-matches for 108 countries within a 0.1 distance (Table 2).

After identifying matches we compute the relative growth rates of every country with respect to each of the matched countries as in (2). By doing so, we obtain our dependent variable $\widetilde{Y}_{i t}$ as in equation (4). We estimate the impact of the relative resource abundance variable to the relative growth rate variable.

It is crucial to note what is meant by resource abundance. Sala-i-Martin et al. (2004) define the mining share of GDP as the resource abundance measure. Sachs and Warner $(1995,1997)$ consider primary exports as an indicator of resource richness. Primary sector products include agriculture, fishing, forestry, minerals and fuels. These primary products have different characteristics in terms of exhaustibility and renewability. If agricultural, fishing and forestry products are non-exhaustible and renewable; however, mining and quarrying products are non-renewable and exhaustible in the predictable future. Additionally, considering the different nature of primary products, in this paper we separate exhaustible and non-renewable resources from non-exhaustible and renewable resources. In other words, different from Sachs and Warner (1995) and others, we would like to focus on exhaustible resources as well. Here, exhaustible resources include only mineral resources that are fuels, ores and metals. Having identified minerals as the focus natural resources, our resource abundance measure will be the mineral exports share of the total merchandise exports taken from the World Development Indicators 2007 by the World Bank covering the period 1960-2004.

After choosing different measures of resource abundance, we estimate the impact of relative resource abundance on relative growth. The estimation yields the results shown in Table 3. One can argue that the observations in our expanded sample are correlated. To 
avoid this, we use a bootstrapping method to estimate the standard errors of the coefficients. The table shows that there is either a strong negative or, in a few cases, no relationship between relative resource abundance and relative growth depending on which resource abundance measure and time periods are selected. The only resource abundance measure that has a positive and significant impact on relative growth is the PXI70 variable.

In addition, as each pair of countries has a different degree of similarity based on the vector distance measure, we would like to weight every observation (pair) by its assigned distance measure. In other words, we will also apply weighted least squares (WLS) estimation using distance as the weighting criterion. ${ }^{4}$ The WLS estimation yields the results seen in Table 4.

Table 4 shows that the results have not changed much when using WLS estimation. This may indicate successful choice of threshold value $\bar{S}$, so that countries lying within that distance from a focus country might be comparable to it.

In Table 3 (and similarly in Table 4), the results (2)-(2) and (2)-(5) show that there is no relationship between growth and the share of exports of primary products in GNP (SXP), which is in contrast to what has been claimed by SW. Furthermore, (5)-(2) and (5)(5) show there to be a positive association between growth and the ratio of primary exports to total merchandise exports (PXI70). This clearly contradicts the claim that resource abundance slows down economic growth.

On the other hand, the results (4)-(2) and (4)-(5) indicate that there is a strong negative link between growth and the share of mineral production in GDP (SNR), which is similar to the results obtained by SW, namely that resource abundance has a negative impact on

\footnotetext{
${ }^{4}$ As different countries have a different number of matched pairs, we also looked at the weighting observations by number of available pairs for each country. The results do not differ significantly from the ones in Table 3 and 4, and hence are not reported here.
} 
growth. Additionally, the results (6)-(2), (6)-(5), (7)-(3) and (7)-(6) suggest that the mineral exports share of total merchandise exports (MINxx_yy) has a significant negative impact on growth.

In order to interpret these differences in results, it is important to understand the differences in the measures of resource abundance. We have considered two types of resource abundance measures based on: 1) primary products (like SXP and PXI70); and 2) mineral products (like SNR, MINING and MINxx_yy). In general, mineral products are perceived to be exhaustible. On the other hand, primary products include exhaustible and non-exhaustible resources as well.

According to the Standard International Trade Classification, primary products are wider-ranging than mineral products, and include: Food and live animals (SITC 0), beverages and tobacco (SITC 1), Crude materials, inedible, except fuels (SITC 2), mineral fuels, lubricants and related materials (SITC 3), animal and vegetable oils and fats (SITC 4) and non-ferrous metals (SITC 68).

We claim that the differences originate from the nature of the resource abundance measures: non-exhaustible resources may have a different impact on growth than exhaustible resources. The empirical evidence in this paper supports our claim. In other words, the resource measures based on primary products, which include also nonexhaustible resources, either have a positive impact on growth or have no impact at all. However, the empirical evidence with resource measures based on mineral resources suggests that there is a strong negative association between growth and resource richness.

If we compare the results with PXI70 (the share of primary exports in total merchandise exports) and MIN66_70 (the share of mineral exports in total merchandise exports) then we see that primary exports have a positive effect on growth whereas mineral exports have a negative impact. 


\subsection{Consistency check with Sala-i-Martin et al. (2004) results}

In Table 3 (and Table 4), the results (1)-(1) show that there is no relationship between growth and the mining and quarrying fraction of GDP (MINING), which is contradictory to what has been claimed by Sala-i-Martin et al. (2004).

Sala-i-Martin et al (2004) (SM) have identified 18 variables that are robustly related to economic growth. Among those 18 variables, there is a resource variable, defined as the mining share of GDP, that has a positive impact on growth. This result contrasts with our results and with what has been found earlier by Sachs and Warner (1995, 1997, 2001), Gylfason (2001) and others. Sala-i-Martin et al. (2004) claim that by including more explanatory variables, the positive effect of resources on growth gets stronger. Therefore, it is important to justify our results in comparison to SM's results. But first, we need to understand those differences.

To do so, first of all, using SM's dataset we estimate growth regression (3) by including all 18 robust explanatory variables shown in SM. The regression estimation in Table 5 shows that, indeed, the mining share of GDP (resource variable) has a positive impact on growth confirming SM's results.

Using the estimation results, we divide the growth rate of a country into two parts: non-resource-based growth $(N B G)$ and resource-based growth (RBG) (including error term). After knowing the regression results of (3) we compute resource-based growth as follows:

$$
R B G=Y_{i t}-N B G=Y_{i t}-\hat{\delta}_{0}-X_{i t}^{\prime} \hat{\beta}=\hat{\alpha} R_{i t}+\hat{\eta}_{i}+\hat{\varepsilon}_{i t}
$$


SM's results show that resource abundance is positively related to growth; this implies that as resources increase then resource-based growth also increases, as shown in Figure 1. That is, the coefficient $\hat{\alpha}$ has a positive sign.

We also calculate the error term of the regression. To see whether there is an omitted variable issue with this regression, we check the sample correlations between the error term and other explanatory variables, shown in Table 6. It is important to note that the error term in regression (3) contains country-specific characteristics $\eta_{i}$ as well.

Table 6 indicates that there is a strong correlation between the error term and explanatory variables, which leads to a bias in the regression coefficients. This creates a suspicion that there is an omitted variable bias. We therefore use a matching method to control for those omitted variables. The main assumption in using matching is that there is a correlation between observables and unobservables, and matching countries based on observables will help not only control for observables but also control for unobservables.

We apply the matching methodology to the obtained regression results. In other words, we use the already matched countries in Table 3, and calculate relative resource-based growth rates and relative resource abundance. Interestingly, the sign of $\hat{\alpha}$ is negative, opposite to the original regression (3) results (Figure 2).

Figure 2 shows that relative resource richness has a negative impact on the relative resource-based growth rate. If we assume that SM's regression is valid, then crosssectional differencing would still yield a positive effect on relative growth rates. However, we obtain the opposite result - that the relative growth rate is negatively related to relative resource abundance. Using SM's dataset and SM's measure of resource abundance, we compare the results found earlier with other measures of resource abundance. In other words, even using the same dataset our results are in contrast to SM's results. This may point to an omitted variable problem in SM's estimation. This leads, in turn, to the 
conclusion that these differences in results are due to differences between our methodology and SM's methodology.

\subsection{Time-series evidence}

Here, we focus on understanding the resource impact from a time-series perspective. Having identified the matches, we would like to understand the relative GDP growths of the similar countries over time. To understand the effect of resource richness, we identify a country that has discovered significant resources so that we can analyze comparatively how the growth of this country has been affected with respect to a matched country.

We identify 14 countries that have significant increases of resource export shares in total merchandise exports over the available dataset 1960-2003. We understand a significant increase to mean that in a particular year the difference between next year's export share and the previous year's export share is bigger than $20 \%$ and that this increase persists over the next 10 years. Those 14 countries are: Angola, Cameroon, the Republic of Congo, Ecuador, Egypt, Mauritania, Mexico, Morocco, Niger, Nigeria, Norway, Papua New Guinea, Senegal and Togo.

Table 7 depicts identified matches and break dates obtained as per the procedure. For example, Cameroon has been matched with 5 countries: Uganda, Namibia, Nigeria, Ghana and Cote d'Ivoire. As noted above, we find the year in which the first occurrence of the difference between next year's export share and the previous year's export share is bigger than 20\%; for Cameroon this is 1978 . Figure 3 shows Cameroon's GDP per capita relative to each matched country. If we take the simple geometric average of per capita GDPs of matched countries, then the graph appears as in Figure 4. Here, year 0 coincides with the break date 1978 . 
For Mauritania we could not identify reasonable matches within an acceptable distance. For Papua New Guinea, although there are 4 matched countries, Western Samoa, Solomon Islands, Tonga, and Vanuatu, neither of these countries has GDP per capita data available in PWT. Therefore, we cannot display their graph of comparison with respect to matched countries. Likewise, we cannot consider Angola from the time-series perspective, as there is no per capita GDP data available in PWT.

Figures 3 through 22 (for each "treatment" country), and Figure 23 (for all countries average) also show interesting patterns. After a break date there is an almost decade-long GDP per capita over performance for resource-rich countries, followed by a long period of under-performance. At a later stage, relative GDP performance stabilizes at a certain level. Stabilization of the relative per capita GDP can be at a higher or lower level compared to the pre-break date level. This may tell us that there is no long-term growth effect of the resources.

\section{Concluding remarks}

In this paper, we analyse the impact of resource richness on a country's GDP per capita performance with respect to another similar country. Using non-parametric minimum vector distance matching yields up to 390 matched pairs depending on which measure of resource abundance is used. After identifying the matched pairs, we estimate the effect of resource abundance differences on GDP per capita growth differences. We use different resource abundnace measures as well as different time periods.

Cross-country evidence shows that the relationship between relative resource richness and relative growth is not stable, depending on which abundance measure is used. In other words, depending on whether a primary products-based resource abundance measure or mineral products-based resource abundance measure is used, the nature of the results are 
different in these cases. In the case of primary products resource measures (SXP and PXI70), the resource impact on growth is either not significant (SXP) or strongly positive (PXI70). However, if we use mineral resource measures then in nearly all cases the effect appears negative and statistically significant.

Interestingly, if the mining share of GDP is used as a resource variable, then it also has a strong negative effect on relative growth over the 1960-1996 period - in line with Sala-iMartin et al. (2004) - and the coefficient is significant at the 1 percent significance level. If we extend the time period to 1960-2003, however, the coefficient loses its statistical significance; it is significant only at 10 percent. These results are contradictory to what was obtained by Sala-i-Martin et al. (2004) who claim that the mining share of GDP has a positive effect on GDP growth. In this paper, we replicate their estimation and show that their estimation is subject to omitted variable bias. In this respect, the matching methodology we employ aims to control for country-specific unobservables which puts the estimation in an advantageous position. Indeed, the effect is opposite to what was claimed by Sala-i-Martin et al. (2004).

In all other cases, the effect appears statistically insignificant. This leads us to claim that the effect of resource richness on growth does not pass the time test. That is, by changing time period the estimation results also change and become insignificant. Lederman and Maloney (2002) reached the same conclusion about the failure to pass the test of time. We, thus, conclude that resource richness has no permanent effect on GDP growth over the long-term.

Furthermore, we look at time series evidence. Having identified the matched pairs we analyze relative GDP per capita from the time-series perspective. The question we wish to answer is what the relative GDP per capita performance of a resource-rich country was with respect to a comparison country before and after it became resource rich. We 
identified 14 countries that show a significant increase of resource export shares in total merchandise exports over the available dataset during 1960-2003: Angola, Cameroon, the Republic of Congo, Ecuador, Egypt, Mauritania, Mexico, Morocco, Niger, Nigeria, Norway, Papua New Guinea, Senegal and Togo. By as a significant increase we mean that in a particular year the difference between next year's export share and the previous year's export share is bigger than $20 \%$ and that this increase persists over next 10 years.

The time-series evidence shows a significant increase in relative GDP during the first 10 years, on average, after the resource abundance increase. Afterwards, the relative GDP per capita growth is negative for a longer time. In other words, there is a boom for a short time followed by long period of bust. The length of the boom and bust periods varies depending on the country under consideration, though on average, the bust period is 20 years. Seemingly, after a long bust period the relative GDP remains stable. This leads us to conclude that in the very long term, resource abundance has only a level effect on per capita GDP.

\section{References}

Auty R.M. (2001a) “The Political Economy of Resource-Driven Growth”, European Economic Review, 45, pp.839-846

Auty R.M. (2001b) "Resource Abundance and Economic Development", Oxford University Press, New York

Cerny A. and Filer R. K. (2007) "Natural Resources: Are They Really a Curse?", CERGEEI Working Paper 321

Davis G. (1995) "Learning to Love the Dutch Disease: Evidence from the Mineral Economies", World Development, 23(10), pp. 1765-1779 
Dehejia R. H. and Wahba S. (2002) "Propensity Score-Matching Methods for Nonexperimental Causal Studies", The Review of Economics and Statistics, February, 84(1), pp. 151-161

Ding N. and Field B. C. (2005) "Natural Resource Abundance and Economic Growth", Land Economics, November, 81(4), pp. 496-502

Eika T. and Magnussen K.A. (1998) "Did Norway Gain from the 1979-85 Oil Price Shock?", Discussion paper No. 210, Statistics Norway, Research Department

Gylfason T. (2001) "Natural Resources, Education and Economic Development", European Economic Review, 45, pp.847-859

Gylfason T. and Zoega G. (2006) "Natural Resources and Economic Growth: The Role of Investment", The World Economy, 29(8), pp. 1091-1115

Heckman J. J., Ichimura H. and Todd P. E. (1997) "Matching As an Econometric Evaluation Estimator: Evidence from Evaluating a Job Training Program", Review of Economic Studies, 64, pp. 605-654

Heston A., Summers R. and Aten B. (2006) "Penn World Table Version 6.2", Center for International Comparisons of Production, Income and Prices at the University of Pennsylvania, September 2006

Lederman D. and Maloney W. (2002) “Open Questions About the Link Between Natural Resources and Economic Growth: Sachs and Warner Revisited", Central Bank of Chile Working paper 141

Levine R. and Renelt D. (1992) "A Sensitivity Analysis of Cross-Country Growth Regressions", American Economic Review, Vol. 82, No. 4, pp. 942-960

Manzano O. and Rigobon R. (2001) "Resource Curse or Debt Overhang?", NBER Working Paper 8390 
Roed Larsen E. (2003) "Are Rich Countries Immune to the Resource Curse? Evidence from Norway's Management of Its Oil Riches", Discussion paper No. 362, Statistics Norway, Research Department

Roed Larsen E. (2004) "Escaping the Resource Curse and the Dutch Disease? When and Why Norway Caught up with and Forged Ahead of Its Neighbors", Discussion paper No. 377, Statistics Norway, Research Department

Rosenbaum P. R. and Rubin D. B. (1983) "The central role of the propensity score in observational studies for causal effects", Biometrica, 70 (1), pp. 41-55

Rubin D. B. (1973) "The Use of Matched Sampling and Regression Adjustment to Remove Bias in Observational Studies", Biometrica, 29, pp. 185-203

Sachs J. D. and Warner A. M. (1995) "Natural Resource Abundance and Economic Growth", NBER Working Paper 5398

Sachs J. D. and Warner A. M. (1997) "Natural Resource Abundance and Economic Growth", mimeo, Center for International Development and Harvard Institute for International Development, Harvard University

Sachs, J. D. and Warner A. M. (1999) "The Big Push, Natural Resource Booms and Growth", Journal of Development Economics, 59(1), pp. 43-76

Sachs J. D. and Warner A. M. (2001) "Natural Resources and Economic Development: The Curse of Natural Resources", European Economic Review, 45, May, pp. 827-838

Sala-i-Martin X., Doppelhofer G. and Miller R.I. (2004) "Determinants of Long-term Growth: A Bayesian Averaging of Classical Estimates (BACE) Approach”, American Economic Review, 94(4), pp.813-835

Stijns J. P. (2001) "Natural Resource Abundance and Economic Growth Revisited", Unpublished manuscript, University of California at Berkeley 
Torvik, R. (2002) "Natural Resources, Rent Seeking, and Welfare", Journal of Development Economics, 67(2), pp. 455-470

van Wijnbergen, S. (1984) "The "Dutch Disease": A Disease After All?", Economic Journal, 94, pp. 41-55

\section{Data}

GR7003 Average GDP per capita growth (constant prices: Laspeyres) over the 19702003 period. Source: Heston, Summers and Aten (2006). Average growth is computed as:

$\frac{1}{33} \sum_{i=1}^{33}\left[\frac{Y_{1970+i}}{Y_{1970+i-1}} \cdot 100-100\right]$

MINING the fraction of GDP produced in the Mining and Quarrying sector. Data are for the year 1988 when possible, or the closest available year. Source: Hall and Jones (1999)

MINxx-yy Fuels exports plus Ores and Metals exports as a percentage of total merchandise exports, average over period 19xx-19yy. Source: World development Indicators 2007, World Bank

SXP Share of exports of primary products in GNP in 1970. Primary products or natural resource exports are exports of "fuels" and "non-fuel primary products". Non-fuel primary products correspond to SITC categories $0,1,2,4$, and 68. Fuels correspond to SITC category 3. These categories are from revision 1 of the SITC. Source: Sachs and Warner (1997)

PXI70 Primary export intensity in 1970. Ratio of primary exports to total merchandise exports in 1970. See SXP for the definition of primary exports. Source: Sachs and Warner (1997) 
SNR The share of mineral production in GNP in 1971. $S N R=\frac{M 71 * 1000}{G N P D 71 * P O P 70}$, where, M71 is the value of mineral production in 1971. This is calculated by Sachs and Warner (1997) from price and quantity data as: $M 71_{j}=\sum_{j=1}^{23} p_{i} \cdot m q_{i j}$. The sum is over 23 minerals.

All other variables were taken from Sala-i-Martin et al (2004). 


\section{Tables}

Table 1: 17 variables used for matching from Sala-i-Martin et al. (2004)

\begin{tabular}{|c|c|c|}
\hline No & $\begin{array}{l}\text { Variable } \\
\text { name }\end{array}$ & Description and source \\
\hline 1 & EAST & Dummy for East Asian countries \\
\hline 2 & P60 & Enrollment rate in primary education in 1960 \\
\hline 3 & IPRICE1 & $\begin{array}{l}\text { Average investment price level between } 1960 \text { and } 1964 \text { on purchasing } \\
\text { power parity basis }\end{array}$ \\
\hline 4 & GDPCH60L & Logarithm of GDP per capita in 1960 \\
\hline 5 & TROPICAR & Proportion of country's land area within geographical tropics \\
\hline 6 & DENS65C & Coastal (within $100 \mathrm{~km}$ of coastline) population per coastal area in 1965 \\
\hline 7 & MALFAL66 & Index of malaria prevalence in 1966 \\
\hline 8 & LIFE060 & Life expectancy in 1960 \\
\hline 9 & CONFUC & Fraction of population Confucian \\
\hline 10 & SAFRICA & Dummy for Sub-Saharan African countries \\
\hline 11 & LAAM & Dummy for Latin American countries \\
\hline 12 & SPAIN & Dummy variable for former Spanish colonies \\
\hline 13 & YRSOPEN & Number of years economy has been open between 1950-1964 \\
\hline 14 & MUSLIM00 & Fraction of population Muslim in 1960 \\
\hline 15 & BUDDHA & Fraction of population Buddhist in 1960 \\
\hline 16 & AVELF & $\begin{array}{l}\text { Average of five different indices of ethno-linguistic fractionalization, } \\
\text { which is the probability of two random people in a country not speaking } \\
\text { the same language }\end{array}$ \\
\hline 17 & GOVSH61 & Share of expenditures on government consumption to GDP in 1961 \\
\hline
\end{tabular}


Table 2: Matched countries based on covariates in Table 1

\begin{tabular}{|c|c|c|}
\hline "Treatment" country & Matched country & Distance measure \\
\hline DZA Algeria & $\begin{array}{ll}\text { TUN } & \text { Tunisia } \\
\text { BHR } & \text { Bahrain }\end{array}$ & $\begin{array}{l}0.0731 \\
0.0974\end{array}$ \\
\hline AGO Angola & $\begin{array}{ll}\text { SLE } & \text { Sierra Leone } \\
\text { CIV } & \text { Cote d'Ivoire } \\
\text { LBR } & \text { Liberia } \\
\text { NGA } & \text { Nigeria } \\
\text { HVO } & \text { Burkina Faso } \\
\text { GNB } & \text { Guinea-Bissau } \\
\text { GHA } & \text { Ghana } \\
\text { KEN } & \text { Kenya } \\
\text { MLI } & \text { Mali }\end{array}$ & $\begin{array}{l}0.0254 \\
0.0404 \\
0.0670 \\
0.0715 \\
0.0767 \\
0.0783 \\
0.0833 \\
0.0871 \\
0.0973\end{array}$ \\
\hline ARG Argentina & Uruguay & 0.0583 \\
\hline AUS Australia & $\begin{array}{ll}\text { LUX } & \text { Luxembourg } \\
\text { FIN } & \text { Finland } \\
\text { DEU } & \text { Germany, West } \\
\text { AUT } & \text { Austria } \\
\text { ITA } & \text { Italy } \\
\text { DNK } & \text { Denmark } \\
\text { FRA } & \text { France } \\
\text { ISL } & \text { Iceland } \\
\text { IRL } & \text { Ireland } \\
\text { NLD } & \text { Netherlands } \\
\text { CHE } & \text { Switzerland } \\
\text { SWE } & \text { Sweden } \\
\text { ESP } & \text { Spain } \\
\text { BEL } & \text { Belgium } \\
\text { USA } & \text { United States } \\
\text { CAN } & \text { Canada } \\
\end{array}$ & $\begin{array}{l}0.0618 \\
0.0640 \\
0.0703 \\
0.0737 \\
0.0739 \\
0.0748 \\
0.0765 \\
0.0774 \\
0.0823 \\
0.0834 \\
0.0835 \\
0.0883 \\
0.0895 \\
0.0917 \\
0.0922 \\
0.0954 \\
\end{array}$ \\
\hline AUT Austria & $\begin{array}{ll}\text { DEU } & \text { Germany, West } \\
\text { FRA } & \text { France } \\
\text { FIN } & \text { Finland } \\
\text { ITA } & \text { Italy } \\
\text { SWE } & \text { Sweden } \\
\text { LUX } & \text { Luxembourg } \\
\text { BEL } & \text { Belgium }\end{array}$ & $\begin{array}{l}0.0204 \\
0.0272 \\
0.0278 \\
0.0312 \\
0.0464 \\
0.0686 \\
0.0851\end{array}$ \\
\hline BHS Bahamas, The & $\begin{array}{ll}\text { GRD } & \text { Grenada } \\
\text { JAM } & \text { Jamaica } \\
\text { BRB } & \text { Barbados } \\
\text { VCT } & \text { St.Vincent \& Grens. } \\
\text { BRA } & \text { Brazil } \\
\text { TTO } & \text { Trinidad \& Tobago } \\
\text { GUY } & \text { Guyana }\end{array}$ & $\begin{array}{l}0.0004 \\
0.0059 \\
0.0342 \\
0.0367 \\
0.0795 \\
0.0844 \\
0.0928\end{array}$ \\
\hline BHR Bahrain & Morocco & 0.0920 \\
\hline
\end{tabular}


Table 2 continued

\begin{tabular}{|c|c|c|c|}
\hline BRB $\quad$ Barbados & $\begin{array}{l}\text { GRD } \\
\text { VCT }\end{array}$ & $\begin{array}{l}\text { Grenada } \\
\text { St.Vincent \& Grens. }\end{array}$ & $\begin{array}{l}0.0298 \\
0.0680\end{array}$ \\
\hline BEL Belgium & $\begin{array}{l}\text { LUX } \\
\text { FIN } \\
\text { FRA } \\
\text { ITA } \\
\text { DEU }\end{array}$ & $\begin{array}{l}\text { Luxembourg } \\
\text { Finland } \\
\text { France } \\
\text { Italy } \\
\text { Germany, West }\end{array}$ & $\begin{array}{l}0.0441 \\
0.0737 \\
0.0741 \\
0.0748 \\
0.0806\end{array}$ \\
\hline BOL Bolivia & $\begin{array}{l}\text { PER } \\
\text { GTM }\end{array}$ & $\begin{array}{l}\text { Peru } \\
\text { Guatemala } \\
\end{array}$ & $\begin{array}{l}0.0812 \\
0.0972\end{array}$ \\
\hline BRA Brazil & $\begin{array}{l}\text { GRD } \\
\text { VCT } \\
\text { DOM }\end{array}$ & $\begin{array}{l}\text { Grenada } \\
\text { St.Vincent \& Grens. } \\
\text { Dominican Rep. }\end{array}$ & $\begin{array}{l}0.0226 \\
0.0548 \\
0.0990\end{array}$ \\
\hline HVO Burkina Faso & $\begin{array}{l}\text { ETH } \\
\text { GNB }\end{array}$ & $\begin{array}{l}\text { Ethiopia } \\
\text { Guinea-Bissau }\end{array}$ & $\begin{array}{l}0.0717 \\
0.0814\end{array}$ \\
\hline CMR Cameroon & $\begin{array}{l}\text { UGA } \\
\text { GHA } \\
\text { CIV }\end{array}$ & $\begin{array}{l}\text { Uganda } \\
\text { Ghana } \\
\text { Cote d'Ivoire }\end{array}$ & $\begin{array}{l}0.0496 \\
0.0930 \\
0.0992\end{array}$ \\
\hline CAN Canada & $\begin{array}{l}\text { USA } \\
\text { CHE } \\
\text { FRA } \\
\text { ISL } \\
\text { BEL } \\
\text { LUX } \\
\text { SWE } \\
\text { FIN } \\
\text { DEU } \\
\text { AUT } \\
\text { DNK } \\
\text { GBR } \\
\text { ESP } \\
\text { NLD } \\
\text { ITA }\end{array}$ & $\begin{array}{l}\text { United States } \\
\text { Switzerland } \\
\text { France } \\
\text { Iceland } \\
\text { Belgium } \\
\text { Luxembourg } \\
\text { Sweden } \\
\text { Finland } \\
\text { Germany, West } \\
\text { Austria } \\
\text { Denmark } \\
\text { United Kingdom } \\
\text { Spain } \\
\text { Netherlands } \\
\text { Italy }\end{array}$ & $\begin{array}{l}0.0513 \\
0.0620 \\
0.0646 \\
0.0685 \\
0.0761 \\
0.0769 \\
0.0806 \\
0.0812 \\
0.0839 \\
0.0850 \\
0.0869 \\
0.0917 \\
0.0932 \\
0.0934 \\
0.0956\end{array}$ \\
\hline CAF Central Afr. Rep. & $\begin{array}{l}\text { TZA } \\
\text { BEN }\end{array}$ & $\begin{array}{l}\text { Tanzania } \\
\text { Benin }\end{array}$ & $\begin{array}{l}0.0945 \\
0.0945\end{array}$ \\
\hline Chad & SDN & Sudan & 0.0773 \\
\hline COL Colombia & $\begin{array}{l}\text { NIC } \\
\text { HON } \\
\text { SLV } \\
\text { MEX }\end{array}$ & $\begin{array}{l}\text { Nicaragua } \\
\text { Honduras } \\
\text { El Salvador } \\
\text { Mexico }\end{array}$ & $\begin{array}{l}0.0663 \\
0.0868 \\
0.0930 \\
0.0967\end{array}$ \\
\hline Costa Rica & $\begin{array}{l}\text { PAN } \\
\text { SLV }\end{array}$ & $\begin{array}{l}\text { Panama } \\
\text { El Salvador }\end{array}$ & $\begin{array}{l}0.0549 \\
0.0722\end{array}$ \\
\hline Cote d'Ivoire & $\begin{array}{l}\text { KEN } \\
\text { GNB } \\
\text { HVO }\end{array}$ & $\begin{array}{l}\text { Kenya } \\
\text { Guinea-Bissau } \\
\text { Burkina Faso }\end{array}$ & $\begin{array}{l}0.0680 \\
0.0852 \\
0.0997\end{array}$ \\
\hline
\end{tabular}


Table 2 continued

\begin{tabular}{|c|c|c|c|c|}
\hline DNK & Denmark & $\begin{array}{l}\text { DEU } \\
\text { AUT } \\
\text { FRA } \\
\text { SWE } \\
\text { FIN } \\
\text { ITA } \\
\text { ISL } \\
\text { IRL } \\
\text { LUX } \\
\text { ESP } \\
\text { BEL }\end{array}$ & $\begin{array}{l}\text { Germany, West } \\
\text { Austria } \\
\text { France } \\
\text { Sweden } \\
\text { Finland } \\
\text { Italy } \\
\text { Iceland } \\
\text { Ireland } \\
\text { Luxembourg } \\
\text { Spain } \\
\text { Belgium }\end{array}$ & $\begin{array}{l}0.0170 \\
0.0268 \\
0.0295 \\
0.0328 \\
0.0408 \\
0.0424 \\
0.0478 \\
0.0587 \\
0.0699 \\
0.0857 \\
0.0880\end{array}$ \\
\hline DMA & Dominica & $\mathrm{LCA}$ & St.Lucia & 0.0338 \\
\hline DOM & Dominican Rep. & $\begin{array}{l}\text { GRD } \\
\text { VCT }\end{array}$ & $\begin{array}{l}\text { Grenada } \\
\text { St.Vincent \& Grens. }\end{array}$ & $\begin{array}{l}0.0044 \\
0.0775\end{array}$ \\
\hline ECU & Ecuador & $\begin{array}{l}\text { PER } \\
\text { BOL }\end{array}$ & $\begin{array}{l}\text { Peru } \\
\text { Bolivia }\end{array}$ & $\begin{array}{l}0.0872 \\
0.0912\end{array}$ \\
\hline SLV & El Salvador & PAN & Panama & 0.0860 \\
\hline$\overline{F J I}$ & Fiji & $\begin{array}{l}\text { SLB } \\
\text { WSM } \\
\text { VUT } \\
\text { TON }\end{array}$ & $\begin{array}{l}\text { Solomon Islands } \\
\text { Samoa } \\
\text { Vanuatu } \\
\text { Tonga }\end{array}$ & $\begin{array}{l}0.0000 \\
0.0000 \\
0.0091 \\
0.0106\end{array}$ \\
\hline FIN & Finland & $\begin{array}{l}\text { ITA } \\
\text { DEU } \\
\text { FRA } \\
\text { LUX } \\
\text { SWE }\end{array}$ & $\begin{array}{l}\text { Italy } \\
\text { Germany, West } \\
\text { France } \\
\text { Luxembourg } \\
\text { Sweden }\end{array}$ & $\begin{array}{l}0.0256 \\
0.0292 \\
0.0385 \\
0.0456 \\
0.0634\end{array}$ \\
\hline FRA & France & $\begin{array}{l}\text { DEU } \\
\text { SWE } \\
\text { ITA } \\
\text { LUX }\end{array}$ & $\begin{array}{l}\text { Germany, West } \\
\text { Sweden } \\
\text { Italy } \\
\text { Luxembourg }\end{array}$ & $\begin{array}{l}0.0291 \\
0.0346 \\
0.0476 \\
0.0665\end{array}$ \\
\hline GAB & Gabon & $\begin{array}{l}\text { CIV } \\
\text { ZWE }\end{array}$ & $\begin{array}{l}\text { Cote d'Ivoire } \\
\text { Zimbabwe }\end{array}$ & $\begin{array}{l}0.0540 \\
0.0754\end{array}$ \\
\hline GMB & Gambia & SDN & Sudan & 0.0857 \\
\hline DEU & Germany, West & $\begin{array}{l}\text { ITA } \\
\text { SWE } \\
\text { LUX }\end{array}$ & $\begin{array}{l}\text { Italy } \\
\text { Sweden } \\
\text { Luxembourg } \\
\end{array}$ & $\begin{array}{l}0.0322 \\
0.0443 \\
0.0588 \\
\end{array}$ \\
\hline GHA & Ghana & UGA & Uganda & 0.0829 \\
\hline GRC & Greece & $\begin{array}{l}\text { IRL } \\
\text { ESP } \\
\text { ITA } \\
\text { FIN } \\
\text { AUT } \\
\text { ISL } \\
\text { FRA } \\
\text { DEU } \\
\text { DNK } \\
\text { BEL }\end{array}$ & $\begin{array}{l}\text { Ireland } \\
\text { Spain } \\
\text { Italy } \\
\text { Finland } \\
\text { Austria } \\
\text { Iceland } \\
\text { France } \\
\text { Germany, West } \\
\text { Denmark } \\
\text { Belgium } \\
\end{array}$ & $\begin{array}{l}0.0494 \\
0.0551 \\
0.0597 \\
0.0667 \\
0.0693 \\
0.0775 \\
0.0819 \\
0.0832 \\
0.0895 \\
0.0988 \\
\end{array}$ \\
\hline
\end{tabular}


Table 2 continued

\begin{tabular}{|c|c|c|c|c|}
\hline GRD & Grenada & $\begin{array}{l}\text { VCT } \\
\text { HTI }\end{array}$ & $\begin{array}{l}\text { St.Vincent \& Grens. } \\
\text { Haiti }\end{array}$ & $\begin{array}{l}0.0004 \\
0.0261\end{array}$ \\
\hline GIN & Guinea & SDN & Sudan & 0.0692 \\
\hline GNB & Guinea-Bissau & KEN & Kenya & 0.0785 \\
\hline GUY & Guyana & $\begin{array}{l}\text { GRD } \\
\text { VCT }\end{array}$ & $\begin{array}{l}\text { Grenada } \\
\text { St.Vincent \& Grens. }\end{array}$ & $\begin{array}{l}0.0991 \\
0.0992\end{array}$ \\
\hline HND & Honduras & SLV & El Salvador & 0.0479 \\
\hline HUN & Hungary & YUG & Yugoslavia & 0.0711 \\
\hline$\overline{\mathrm{ISL}}$ & Iceland & $\begin{array}{l}\text { FRA } \\
\text { AUT } \\
\text { DEU } \\
\text { FIN } \\
\text { ITA } \\
\text { SWE } \\
\text { IRL } \\
\text { BEL } \\
\text { LUX } \\
\text { ESP }\end{array}$ & $\begin{array}{l}\text { France } \\
\text { Austria } \\
\text { Germany, West } \\
\text { Finland } \\
\text { Italy } \\
\text { Sweden } \\
\text { Ireland } \\
\text { Belgium } \\
\text { Luxembourg } \\
\text { Spain } \\
\end{array}$ & $\begin{array}{l}0.0362 \\
0.0398 \\
0.0480 \\
0.0484 \\
0.0519 \\
0.0544 \\
0.0572 \\
0.0665 \\
0.0701 \\
0.0782\end{array}$ \\
\hline IDN & Indonesia & $\begin{array}{l}\text { WSN } \\
\text { SLB }\end{array}$ & $\begin{array}{l}\text { Samoa } \\
\text { Solomon Islands }\end{array}$ & $\begin{array}{l}0.0107 \\
0.0107\end{array}$ \\
\hline IRQ & Iraq & $\begin{array}{l}\text { DZA } \\
\text { TUN }\end{array}$ & $\begin{array}{l}\text { Algeria } \\
\text { Tunisia }\end{array}$ & $\begin{array}{l}0.0746 \\
0.0965\end{array}$ \\
\hline IRL & Ireland & $\begin{array}{l}\text { AUT } \\
\text { FIN } \\
\text { ITA } \\
\text { FRA } \\
\text { DEU } \\
\text { ESP } \\
\text { SWE } \\
\text { LUX } \\
\text { BEL } \\
\text { NZL }\end{array}$ & $\begin{array}{l}\text { Austria } \\
\text { Finland } \\
\text { Italy } \\
\text { France } \\
\text { Germany, West } \\
\text { Spain } \\
\text { Sweden } \\
\text { Luxembourg } \\
\text { Belgium } \\
\text { New Zealand }\end{array}$ & $\begin{array}{l}0.0411 \\
0.0417 \\
0.0425 \\
0.0531 \\
0.0553 \\
0.0542 \\
0.0755 \\
0.0818 \\
0.0863 \\
0.0956 \\
\end{array}$ \\
\hline ITA & Italy & $\begin{array}{l}\text { LUX } \\
\text { SWE }\end{array}$ & $\begin{array}{l}\text { Luxembourg } \\
\text { Sweden }\end{array}$ & $\begin{array}{l}0.0591 \\
0.0711\end{array}$ \\
\hline JAM & Jamaica & $\begin{array}{l}\text { GRD } \\
\text { VCT }\end{array}$ & $\begin{array}{l}\text { Grenada } \\
\text { St.Vincent \& Grens. }\end{array}$ & $\begin{array}{l}0.0051 \\
0.0330\end{array}$ \\
\hline LBR & Liberia & $\begin{array}{l}\text { SLE } \\
\text { TGO } \\
\text { GNB } \\
\text { TZA } \\
\text { KEN } \\
\text { MLI } \\
\text { CMR } \\
\text { CIV } \\
\text { HVO } \\
\text { BEN } \\
\text { UGA }\end{array}$ & $\begin{array}{l}\text { Sierra Leone } \\
\text { Togo } \\
\text { Guinea-Bissau } \\
\text { Tanzania } \\
\text { Kenya } \\
\text { Mali } \\
\text { Cameroon } \\
\text { Cote d'Ivoire } \\
\text { Burkina Faso } \\
\text { Benin } \\
\text { Uganda }\end{array}$ & $\begin{array}{l}0.0633 \\
0.0695 \\
0.0696 \\
0.0764 \\
0.0782 \\
0.0795 \\
0.0832 \\
0.0866 \\
0.0873 \\
0.0914 \\
0.0929\end{array}$ \\
\hline
\end{tabular}


Table 2 continued

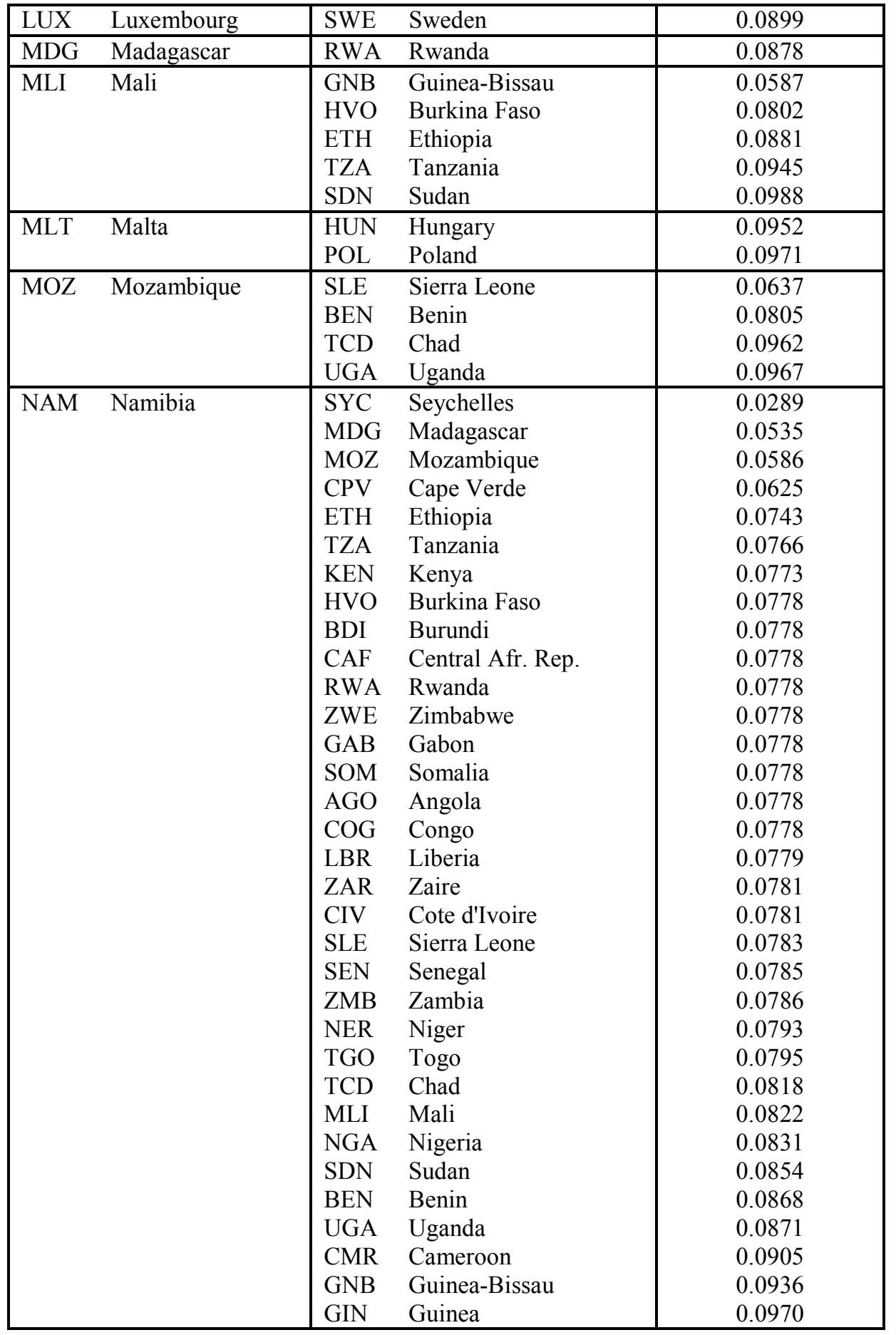


Table 2 continued

\begin{tabular}{|c|c|c|c|}
\hline $\begin{array}{ll}\text { NLD } & \text { Netherlands }\end{array}$ & $\begin{array}{l}\text { DNK } \\
\text { DEU } \\
\text { ITA } \\
\text { ISL } \\
\text { FRA } \\
\text { AUT } \\
\text { FIN } \\
\text { GBR } \\
\text { SWE } \\
\text { LUX } \\
\text { IRL } \\
\text { BEL } \\
\text { USA } \\
\text { ESP } \\
\text { GRC } \\
\text { PRT } \\
\text { CHE }\end{array}$ & $\begin{array}{l}\text { Denmark } \\
\text { Germany, West } \\
\text { Italy } \\
\text { Iceland } \\
\text { France } \\
\text { Austria } \\
\text { Finland } \\
\text { United Kingdom } \\
\text { Sweden } \\
\text { Luxembourg } \\
\text { Ireland } \\
\text { Belgium } \\
\text { United States } \\
\text { Spain } \\
\text { Greece } \\
\text { Portugal } \\
\text { Switzerland }\end{array}$ & $\begin{array}{l}0.0352 \\
0.0363 \\
0.0407 \\
0.0438 \\
0.0459 \\
0.0465 \\
0.0523 \\
0.0535 \\
0.0585 \\
0.0615 \\
0.0664 \\
0.0695 \\
0.0720 \\
0.0805 \\
0.0889 \\
0.0969 \\
0.0988\end{array}$ \\
\hline $\begin{array}{ll}\text { NIC } & \text { Nicaragua }\end{array}$ & $\begin{array}{l}\text { HON } \\
\text { GTM } \\
\text { SLV } \\
\text { PER } \\
\text { MEX }\end{array}$ & $\begin{array}{l}\text { Honduras } \\
\text { Guatemala } \\
\text { El Salvador } \\
\text { Peru } \\
\text { Mexico } \\
\end{array}$ & $\begin{array}{l}0.0650 \\
0.0868 \\
0.0885 \\
0.0946 \\
0.0999 \\
\end{array}$ \\
\hline $\begin{array}{ll}\text { NER } & \text { Niger }\end{array}$ & $\begin{array}{l}\text { MLI } \\
\text { SDN } \\
\text { SEN } \\
\text { SLE } \\
\text { TZA }\end{array}$ & $\begin{array}{l}\text { Mali } \\
\text { Sudan } \\
\text { Senegal } \\
\text { Sierra Leone } \\
\text { Tanzania }\end{array}$ & $\begin{array}{l}0.0711 \\
0.0840 \\
0.0844 \\
0.0964 \\
0.0966\end{array}$ \\
\hline NGA $\quad$ Nigeria & $\begin{array}{l}\text { SLE } \\
\text { CIV } \\
\text { GNB } \\
\text { GHA } \\
\text { LBR } \\
\text { CMR } \\
\text { MLI } \\
\text { ETH } \\
\text { HVO } \\
\text { KEN } \\
\text { GIN } \\
\text { UGA }\end{array}$ & $\begin{array}{l}\text { Sierra Leone } \\
\text { Cote d'Ivoire } \\
\text { Guinea-Bissau } \\
\text { Ghana } \\
\text { Liberia } \\
\text { Cameroon } \\
\text { Mali } \\
\text { Ethiopia } \\
\text { Burkina Faso } \\
\text { Kenya } \\
\text { Guinea } \\
\text { Uganda }\end{array}$ & $\begin{array}{l}0.0671 \\
0.0731 \\
0.0773 \\
0.0841 \\
0.0849 \\
0.0907 \\
0.0920 \\
0.0920 \\
0.0921 \\
0.0924 \\
0.0948 \\
0.0963\end{array}$ \\
\hline PNG Papua New Guinea & $\begin{array}{l}\text { WSM } \\
\text { SLB } \\
\text { TON } \\
\text { VUT }\end{array}$ & $\begin{array}{l}\text { Samoa } \\
\text { Solomon Islands } \\
\text { Tonga } \\
\text { Vanuatu }\end{array}$ & $\begin{array}{l}0.0000 \\
0.0000 \\
0.0000 \\
0.0000 \\
\end{array}$ \\
\hline
\end{tabular}


Table 2 continued

\begin{tabular}{|c|c|c|c|c|}
\hline PER & Peru & $\begin{array}{l}\text { HND } \\
\text { SLV } \\
\text { GTM } \\
\end{array}$ & $\begin{array}{l}\text { Honduras } \\
\text { El Salvador } \\
\text { Guatemala } \\
\end{array}$ & $\begin{array}{l}0.0870 \\
0.0873 \\
0.0894 \\
\end{array}$ \\
\hline PHL & Philippines & $\begin{array}{l}\text { WSM } \\
\text { SLB } \\
\text { VUT } \\
\text { TON }\end{array}$ & $\begin{array}{l}\text { Samoa } \\
\text { Solomon Islands } \\
\text { Vanuatu } \\
\text { Tonga }\end{array}$ & $\begin{array}{l}0.0215 \\
0.0215 \\
0.0234 \\
0.0273\end{array}$ \\
\hline POL & Poland & $\begin{array}{l}\text { HUN } \\
\text { NZL } \\
\text { YUG }\end{array}$ & $\begin{array}{l}\text { Hungary } \\
\text { New Zealand } \\
\text { Yugoslavia }\end{array}$ & $\begin{array}{l}0.0149 \\
0.0394 \\
0.0735\end{array}$ \\
\hline PRT & Portugal & $\begin{array}{l}\text { GRC } \\
\text { IRL } \\
\text { ITA } \\
\text { ESP } \\
\text { AUT } \\
\text { FIN } \\
\text { DEU } \\
\text { FRA } \\
\text { ISL } \\
\text { DNK }\end{array}$ & $\begin{array}{l}\text { Greece } \\
\text { Ireland } \\
\text { Italy } \\
\text { Spain } \\
\text { Austria } \\
\text { Finland } \\
\text { Germany, West } \\
\text { France } \\
\text { Iceland } \\
\text { Denmark }\end{array}$ & $\begin{array}{l}0.0389 \\
0.0581 \\
0.0662 \\
0.0709 \\
0.0753 \\
0.0769 \\
0.0897 \\
0.0926 \\
0.0941 \\
0.0981\end{array}$ \\
\hline RWA & Rwanda & $\mathrm{SYC}$ & Seychelles & 0.0957 \\
\hline WSM & Samoa & $\begin{array}{l}\text { SLB } \\
\text { TON } \\
\text { VUT }\end{array}$ & $\begin{array}{l}\text { Solomon Islands } \\
\text { Tonga } \\
\text { Vanuatu }\end{array}$ & $\begin{array}{l}0.0000 \\
0.0000 \\
0.0000 \\
\end{array}$ \\
\hline SEN & Senegal & SDN & Sudan & 0.0754 \\
\hline$\overline{\text { SLE }}$ & Sierra Leone & $\begin{array}{l}\text { GNB } \\
\text { CIV } \\
\text { CAF } \\
\text { TZA } \\
\text { BEN } \\
\text { TCD } \\
\text { MLI } \\
\text { HVO } \\
\text { ETH } \\
\text { KEN } \\
\text { UGA } \\
\end{array}$ & $\begin{array}{l}\text { Guinea-Bissau } \\
\text { Cote d'Ivoire } \\
\text { Central Afr. Rep. } \\
\text { Tanzania } \\
\text { Benin } \\
\text { Chad } \\
\text { Mali } \\
\text { Burkina Faso } \\
\text { Ethiopia } \\
\text { Kenya } \\
\text { Uganda } \\
\end{array}$ & $\begin{array}{l}0.0442 \\
0.0525 \\
0.0542 \\
0.0566 \\
0.0590 \\
0.0734 \\
0.0737 \\
0.0758 \\
0.0886 \\
0.0966 \\
0.0997 \\
\end{array}$ \\
\hline SLB & Solomon Islands & $\begin{array}{l}\text { TON } \\
\text { VUT }\end{array}$ & $\begin{array}{l}\text { Tonga } \\
\text { Vanuatu }\end{array}$ & $\begin{array}{l}0.0000 \\
0.0000 \\
\end{array}$ \\
\hline ESP & Spain & $\begin{array}{l}\text { FIN } \\
\text { ITA } \\
\text { BEL } \\
\text { LUX } \\
\text { AUT } \\
\text { FRA } \\
\text { DEU } \\
\end{array}$ & $\begin{array}{l}\text { Finland } \\
\text { Italy } \\
\text { Belgium } \\
\text { Luxembourg } \\
\text { Austria } \\
\text { France } \\
\text { Germany, West }\end{array}$ & $\begin{array}{l}0.0530 \\
0.0556 \\
0.0635 \\
0.0678 \\
0.0717 \\
0.0737 \\
0.0766 \\
\end{array}$ \\
\hline LCA & St.Lucia & SUR & Suriname & 0.0744 \\
\hline
\end{tabular}


Table 2 continued

\begin{tabular}{|c|c|c|c|c|}
\hline $\mathrm{CHE}$ & Switzerland & $\begin{array}{l}\text { LUX } \\
\text { USA } \\
\text { FIN } \\
\text { BEL } \\
\text { FRA } \\
\text { ISL } \\
\text { DEU } \\
\text { ESP } \\
\text { ITA } \\
\text { DNK } \\
\text { AUT }\end{array}$ & $\begin{array}{l}\text { Luxembourg } \\
\text { United States } \\
\text { Finland } \\
\text { Belgium } \\
\text { France } \\
\text { Iceland } \\
\text { Germany, West } \\
\text { Spain } \\
\text { Italy } \\
\text { Denmark } \\
\text { Austria } \\
\end{array}$ & $\begin{array}{l}0.0496 \\
0.0724 \\
0.0799 \\
0.0805 \\
0.0889 \\
0.0891 \\
0.0892 \\
0.0904 \\
0.0926 \\
0.0967 \\
0.0969 \\
\end{array}$ \\
\hline SYR & Syria & TUR & Turkey & 0.0437 \\
\hline TGO & Togo & $\begin{array}{l}\text { TZA } \\
\text { SLE } \\
\text { MWI } \\
\text { GNB } \\
\text { CAF }\end{array}$ & $\begin{array}{l}\text { Tanzania } \\
\text { Sierra Leone } \\
\text { Malawi } \\
\text { Guinea-Bissau } \\
\text { Central Afr. Rep. }\end{array}$ & $\begin{array}{l}0.0543 \\
0.0701 \\
0.0954 \\
0.0977 \\
0.0982\end{array}$ \\
\hline TON & Tonga & VUT & Vanuatu & 0.0000 \\
\hline TTO & Trinidad \& Tob. & GRD & Grenada & 0.0948 \\
\hline TUN & Tunisia & $\begin{array}{l}\text { MAR } \\
\text { TUR }\end{array}$ & $\begin{array}{l}\text { Morocco } \\
\text { Turkey }\end{array}$ & $\begin{array}{l}0.0963 \\
0.0969\end{array}$ \\
\hline ARE & United Arab Em. & $\begin{array}{l}\text { BHR } \\
\text { SAU } \\
\text { IRN } \\
\text { DZA } \\
\text { KWT }\end{array}$ & $\begin{array}{l}\text { Bahrain } \\
\text { Saudi Arabia } \\
\text { Iran, I.R. of } \\
\text { Algeria } \\
\text { Kuwait }\end{array}$ & $\begin{array}{l}0.0367 \\
0.0730 \\
0.0859 \\
0.0869 \\
0.0871\end{array}$ \\
\hline GBR & United Kingdom & $\begin{array}{l}\text { SWE } \\
\text { FRA } \\
\text { DNK } \\
\text { DEU } \\
\text { AUT } \\
\text { USA } \\
\text { FIN } \\
\text { ISL } \\
\text { ITA } \\
\text { IRL } \\
\text { BEL } \\
\text { LUX }\end{array}$ & $\begin{array}{l}\text { Sweden } \\
\text { France } \\
\text { Denmark } \\
\text { Germany, West } \\
\text { Austria } \\
\text { United States } \\
\text { Finland } \\
\text { Iceland } \\
\text { Italy } \\
\text { Ireland } \\
\text { Belgium } \\
\text { Luxembourg }\end{array}$ & $\begin{array}{l}0.0339 \\
0.0410 \\
0.0422 \\
0.0490 \\
0.0534 \\
0.0633 \\
0.0685 \\
0.0704 \\
0.0716 \\
0.0781 \\
0.0960 \\
0.0963\end{array}$ \\
\hline USA & United States & $\begin{array}{l}\text { FRA } \\
\text { SWE } \\
\text { DEU } \\
\text { DNK } \\
\text { AUT } \\
\text { FIN } \\
\text { ISL } \\
\text { LUX } \\
\text { ITA } \\
\text { BEL } \\
\end{array}$ & $\begin{array}{l}\text { France } \\
\text { Sweden } \\
\text { Germany, West } \\
\text { Denmark } \\
\text { Austria } \\
\text { Finland } \\
\text { Iceland } \\
\text { Luxembourg } \\
\text { Italy } \\
\text { Belgium } \\
\end{array}$ & $\begin{array}{l}0.0506 \\
0.0558 \\
0.0583 \\
0.0604 \\
0.0680 \\
0.0704 \\
0.0707 \\
0.0738 \\
0.0815 \\
0.0882 \\
\end{array}$ \\
\hline ZMB & Zambia & $\begin{array}{l}\text { LBR } \\
\text { KEN } \\
\text { SLE } \\
\text { TGO } \\
\text { GNB } \\
\end{array}$ & $\begin{array}{l}\text { Liberia } \\
\text { Kenya } \\
\text { Sierra Leone } \\
\text { Togo } \\
\text { Guinea-Bissau } \\
\end{array}$ & $\begin{array}{l}0.0655 \\
0.0659 \\
0.0770 \\
0.0875 \\
0.0889 \\
\end{array}$ \\
\hline ZWE & Zimbabwe & CIV & Cote d'Ivoire & 0.0673 \\
\hline
\end{tabular}


Table 3: The impact coefficients of relative resource abundance on relative growth as in equation (4), OLS estimation, with the bootstrap estimates of the standard errors (replications $=1000$ )

(1)

(2)

(3)

(4)

(5)

(6)

(7)

Bootstrap Std. errs.

R-squared

\# of observations

R-squared

\# of observations

D_SXP

Bootstrap Std. errs.

R-squared

\# of observations

D_SXP80

Bootstrap Std. errs.

R-squared

\# of observations

D_SNR

Bootstrap Std. errs.

R-squared

\# of observations

D_PXI70

Bootstrap Std. errs.

R-squared

\# of observations

D_MIN66-70

Bootstrap Std. errs.

R-squared

D_MIN76-80
(2)

\begin{tabular}{|l|l|l|l|l|l|l|l|}
\hline OLS & SM & SW & SW & PWT & PWT & PWT \\
regression & D_GR6096 & D_GEA7090 & D_GEA8090 & D_GR6003 & D_GR7003 & D_GR8003 & D_G \\
\hline
\end{tabular}

results

D_MINING

Bootstrap Std. errs.

\# of observations

(1) -

\begin{tabular}{c|c|c|}
-0.067 & - & - \\
\hline
\end{tabular}

$0.011 * * *$

0.16 301

\begin{tabular}{l|l}
301 & \\
- &
\end{tabular}

$-0.0009$

\begin{tabular}{l|r|r} 
& & 0.02 \\
\hline & & 230 \\
\hline
\end{tabular}

\begin{tabular}{|c|c|c|c|}
\hline-0.020 & - & - & -0.046 \\
\hline $0.010 * *$ & & & $0.020 * *$ \\
\hline 0.02 & & & 0.02 \\
\hline
\end{tabular}


Table 4: The impact coefficients of relative resource abundance on relative growth as in equation (4), WLS estimation: the weights are the inverses of the distance measure.

(1) (2)

\section{WLS}

regression

results

(1)

(2)

(3)

(4)

(5)

(6)

(7)

)

D_MINING

Std. errs.

R-squared

\# of observations

D_SXP

Std. errs.

R-squared

\# of observations

D_SXP80

Std. errs.

R-squared

\# of observations

D_PXI70

Std. errs.

R-squared

\# of observations

D SNR

Std. errs.

R-squared

\# of observations

D_MIN66-70

Std. errs.

R-squared

\# of observations

D_MIN76-80

Std. errs.

0.14

301

\begin{tabular}{l|l}
- & -0.001
\end{tabular}

\begin{tabular}{|l|l}
\hline & 0.00 \\
- & 232 \\
\hline
\end{tabular}

R-squared

\# of observations

(4)

(6)

(3)

(7)

(8)

\begin{tabular}{|l|l|l|l|l|l|l} 
SM & SW & SW & PWT & PWT & PWT & PW \\
D_GR6096 & D_GEA7090 & D_GEA8090 & D_GR6003 & D_GR7003 & D_GR8003 & D_G
\end{tabular}

WT

D_GR9003

0.016

(2)

$-$

$-$

$-0.055$

$0.019 * * *$

0.02 309

\begin{tabular}{l|l|l} 
& & 230 \\
\hline-0.001 & - & -
\end{tabular}

\begin{tabular}{c|c|c|c}
232 & & & 261 \\
\hline- & -0.017 & - & -
\end{tabular}

\begin{tabular}{|c|c|c|} 
& & -0.017 \\
& $0.007^{* *}$ & \\
0.02 & \\
& 223 & \\
\hline
\end{tabular}

\begin{tabular}{|c|c|}
- & -0.018 \\
& $0.006^{* * *}$ \\
0.03 \\
& 252 \\
\hline
\end{tabular}

\begin{tabular}{|c|c|c|}
\hline 0.013 & - & - \\
$0.003^{* * *}$ & & \\
0.07 & & \\
275 & & \\
\hline-0.043 & - & - \\
$0.004^{* * *}$ & & \\
0.28 & & \\
296 & & \\
-0.015 & - & \\
$0.004^{* * *}$ & & \\
0.05 & & \\
252 & & \\
\hline- & -0.020 & - \\
& $0.004 * * *$ & \\
& 0.11 & \\
\hline
\end{tabular}


Table 5: Replication of Sala-i-Martin et al (2004) results

\begin{tabular}{|c|c|c|}
\hline $\begin{array}{l}\text { Dependent variable: } \\
\text { GR6096 }\end{array}$ & $\begin{array}{l}\text { OLS regression coefficients } \\
\text { and t-stats }\end{array}$ & $\begin{array}{l}\text { Impact coefficient in Sala-i- } \\
\text { Martin et al (2004) }\end{array}$ \\
\hline MINING & $\begin{array}{c}0.038446 \\
(2.70)\end{array}$ & 0.038823 \\
\hline EAST & $\begin{array}{c}0.007611 \\
(1.25)\end{array}$ & 0.021805 \\
\hline P60 & $\begin{array}{c}0.01851 \\
(2.78)\end{array}$ & 0.026852 \\
\hline IPRICE1 & $\begin{array}{c}-0.000077 \\
(-3.66)\end{array}$ & -0.000084 \\
\hline GDPCH60L & $\begin{array}{c}-0.010977 \\
(-4.75)\end{array}$ & -0.008538 \\
\hline TROPICAR & $\begin{array}{c}-0.007121 \\
(-1.52)\end{array}$ & -0.014757 \\
\hline DENS65C & $\begin{array}{c}0.000004 \\
(1.69)\end{array}$ & 0.000009 \\
\hline MALFAL66 & $\begin{array}{c}-0.001272 \\
(-0.24)\end{array}$ & -0.015702 \\
\hline LIFE060 & $\begin{array}{l}0.000532 \\
(2.16)\end{array}$ & 0.000808 \\
\hline CONFUC & $\begin{array}{l}0.034218 \\
(1.90)\end{array}$ & 0.054429 \\
\hline SAFRICA & $\begin{array}{c}-0.006033 \\
(-1.15)\end{array}$ & -0.014706 \\
\hline LAAM & $\begin{array}{c}-0.001916 \\
(-0.29)\end{array}$ & -0.012758 \\
\hline SPAIN & $\begin{array}{c}-0.004475 \\
(-0.83)\end{array}$ & -0.010720 \\
\hline YRSOPEN & $\begin{array}{c}0.005226 \\
(1.04)\end{array}$ & 0.012209 \\
\hline MUSLIM00 & $\begin{array}{c}0.007401 \\
(1.65)\end{array}$ & 0.012629 \\
\hline BUDDHA & $\begin{array}{c}0.012106 \\
(1.44)\end{array}$ & 0.021667 \\
\hline AVELF & $\begin{array}{c}-0.003050 \\
(-0.60)\end{array}$ & -0.011281 \\
\hline GOVSH61 & $\begin{array}{c}-0.021675 \\
(-1.26)\end{array}$ & -0.044171 \\
\hline R-squared & 0.8044 & - \\
\hline \# of countries & 96 & 96 \\
\hline
\end{tabular}


Table 6: The correlations between error term and explanatory variables as per regression (3)

\begin{tabular}{|l|c|c|}
\hline & $\begin{array}{c}\text { ERROR } \\
\text { TERM }\end{array}$ & MINING \\
\hline GR6096 & 0.964 & -0.151 \\
\hline MINING & -0.193 & 1.000 \\
\hline PAST & 0.563 & -0.035 \\
\hline IPRICE1 & 0.619 & -0.118 \\
\hline GDPCH60L & -0.454 & 0.012 \\
\hline TROPICAR & 0.349 & -0.064 \\
\hline DENS65C & -0.496 & 0.074 \\
\hline MALFAL66 & 0.470 & -0.132 \\
\hline LIFE060 & -0.619 & 0.182 \\
\hline CONFUC & 0.623 & -0.196 \\
\hline SAFRICA & 0.510 & -0.083 \\
\hline LAAM & -0.637 & 0.069 \\
\hline SPAIN & -0.108 & -0.084 \\
\hline YRSOPEN & -0.109 & -0.065 \\
\hline MUSLIM00 & 0.677 & -0.189 \\
\hline BUDDHA & -0.002 & 0.300 \\
\hline AVELF & 0.490 & -0.116 \\
\hline GOVSH61 & -0.479 & 0.244 \\
\hline
\end{tabular}


Table 7: Time-series comparison of per capita GDP for matched countries before and after a break date

\begin{tabular}{|c|c|c|c|}
\hline "Treatment" country & Matched Countries & Break year & $\begin{array}{l}\text { Relative GDP } \\
\text { performance }\end{array}$ \\
\hline Angola & $\begin{array}{l}\text { Sierra Leone, Cote } \\
\text { d'Ivoire, Liberia, } \\
\text { Nigeria, Burkina Faso, } \\
\text { Guinea-Bissau, Ghana, } \\
\text { Kenya and Mali }\end{array}$ & 1973 & $\begin{array}{l}\text { For Angola, there is no } \\
\text { per capita GDP data } \\
\text { available in PWT }\end{array}$ \\
\hline Cameroon & $\begin{array}{l}\text { Uganda, Namibia, } \\
\text { Nigeria, Ghana and Cote } \\
\text { d'Ivoire }\end{array}$ & 1978 & $\begin{array}{l}\text { refer to Figure } 3 \text { and } \\
\text { Figure } 4\end{array}$ \\
\hline Congo & Namibia and Benin & 1972 & Figure 5 and Figure 6 \\
\hline Ecuador & $\begin{array}{l}\text { Peru, Bolivia and El } \\
\text { Salvador }\end{array}$ & 1972 & Figure 7 and Figure 8 \\
\hline Egypt & United Arab Emirates & 1978 & Figure 9 \\
\hline Mauritania & $\begin{array}{l}\text { no matches identified } \\
\text { within defined distance }\end{array}$ & 1962 & not available \\
\hline Mexico & Colombia and Nicaragua & 1980 & Figure 10 and Figure 11 \\
\hline Morocco & Bahrain and Tunisia & 1974 & Figure 12 and Figure 13 \\
\hline Niger & $\begin{array}{l}\text { Mali, Namibia, Sudan, } \\
\text { Senegal, Sierra Leone } \\
\text { and Tanzania }\end{array}$ & 1973 & Figure 14 and Figure 15 \\
\hline Nigeria & $\begin{array}{l}\text { Cote d'Ivoire, Guinea- } \\
\text { Bissau, Ghana, Mali, } \\
\text { Ethiopia, Burkina Faso, } \\
\text { Kenya, Guinea and } \\
\text { Uganda }\end{array}$ & 1968 & Figure 16 and Figure 17 \\
\hline Norway & $\begin{array}{l}\text { Iceland, Austria, } \\
\text { Finland, France, Italy, } \\
\text { Sweden, Ireland, } \\
\text { Sweden, Netherlands, } \\
\text { Luxembourg, United } \\
\text { Kingdom, United States } \\
\text { of America, Spain, } \\
\text { Greece, Belgium, } \\
\text { Switzerland and } \\
\text { Portugal }\end{array}$ & 1978 & Figure 18 and Figure 19 \\
\hline Papua New Guinea & $\begin{array}{l}\text { Western Samoa, } \\
\text { Solomon Islands, Tonga } \\
\text { and Vanuatu }\end{array}$ & 1972 & $\begin{array}{l}\text { No GDP per capita data } \\
\text { is available for matched } \\
\text { countries in PWT }\end{array}$ \\
\hline Senegal & Sudan & 1980 & Figure 20 \\
\hline Togo & $\begin{array}{l}\text { Tanzania, Zambia, } \\
\text { Malawi and Guinea- } \\
\text { Bissau }\end{array}$ & 1962 & Figure 21 and Figure 22 \\
\hline
\end{tabular}




\section{Figures}

Figure 1: Resource-based growth and resource abundance

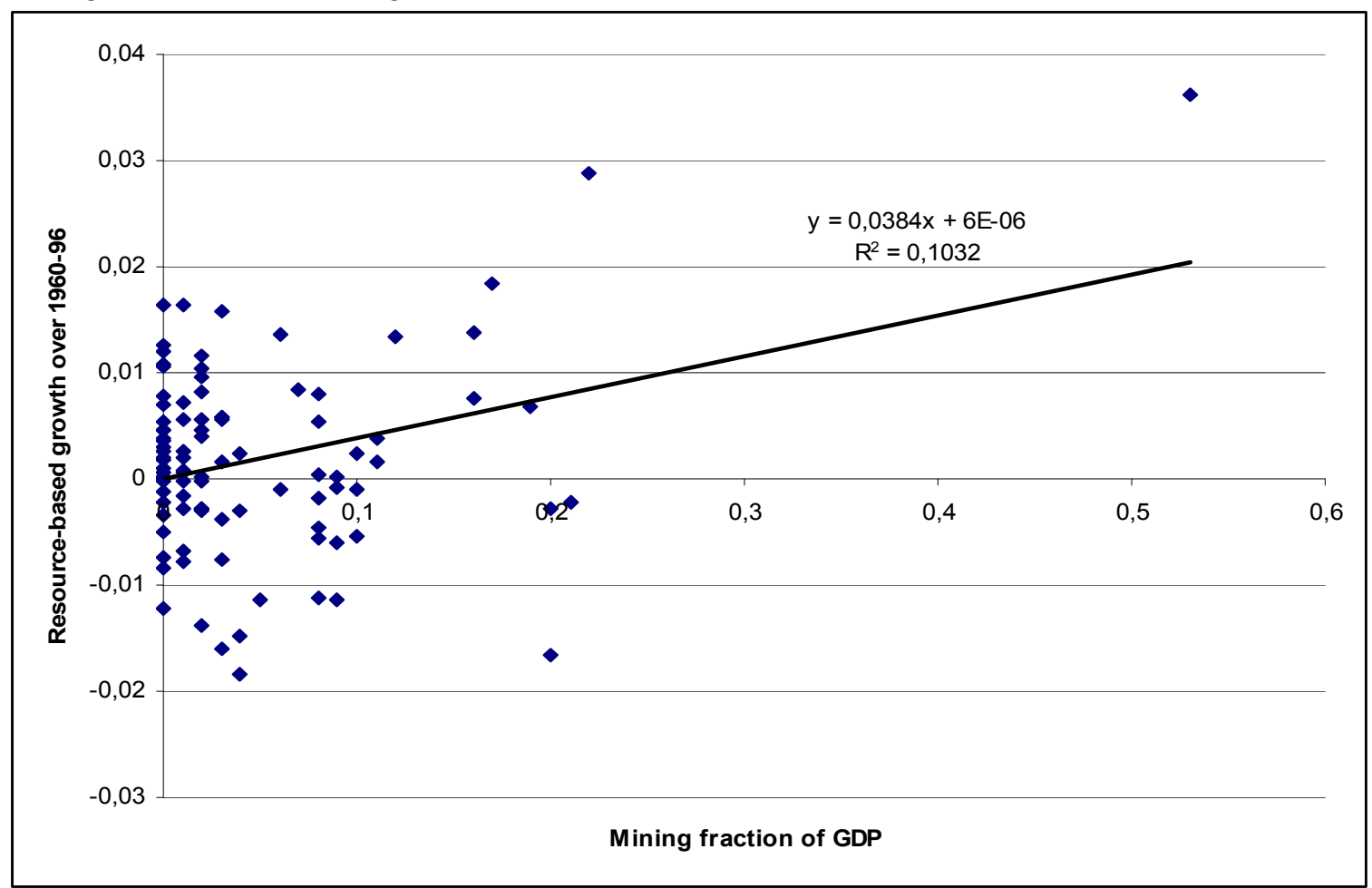

Figure 2: The relative resource richness and relative resource-based growth

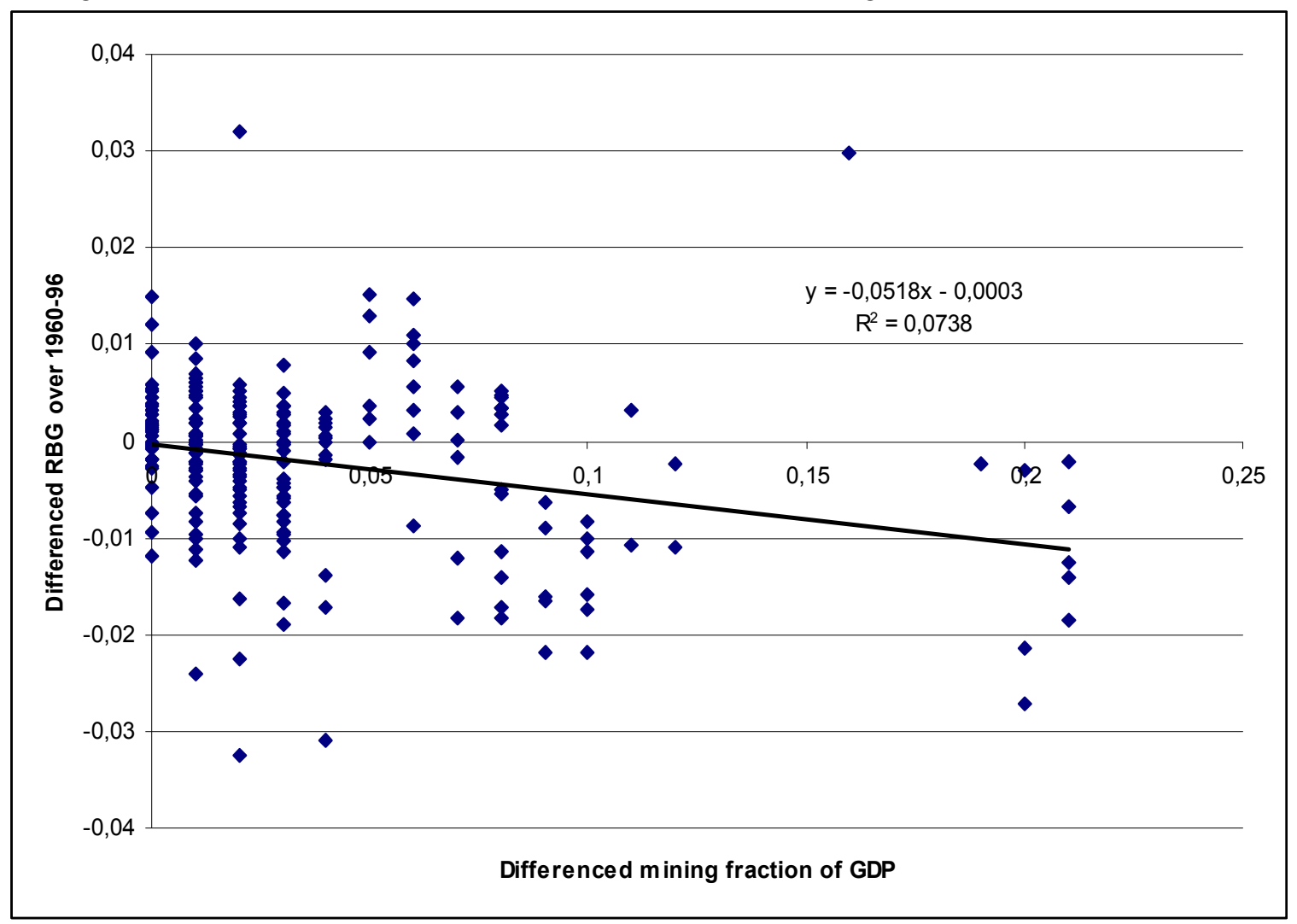


Figure 3: Cameroon with respect to Uganda, Namibia, Nigeria, Ghana and Cote d'Ivoire Relative real GDP per capita ( $\$$ in 2000 Constant Prices: Lasp.) $1978=100$

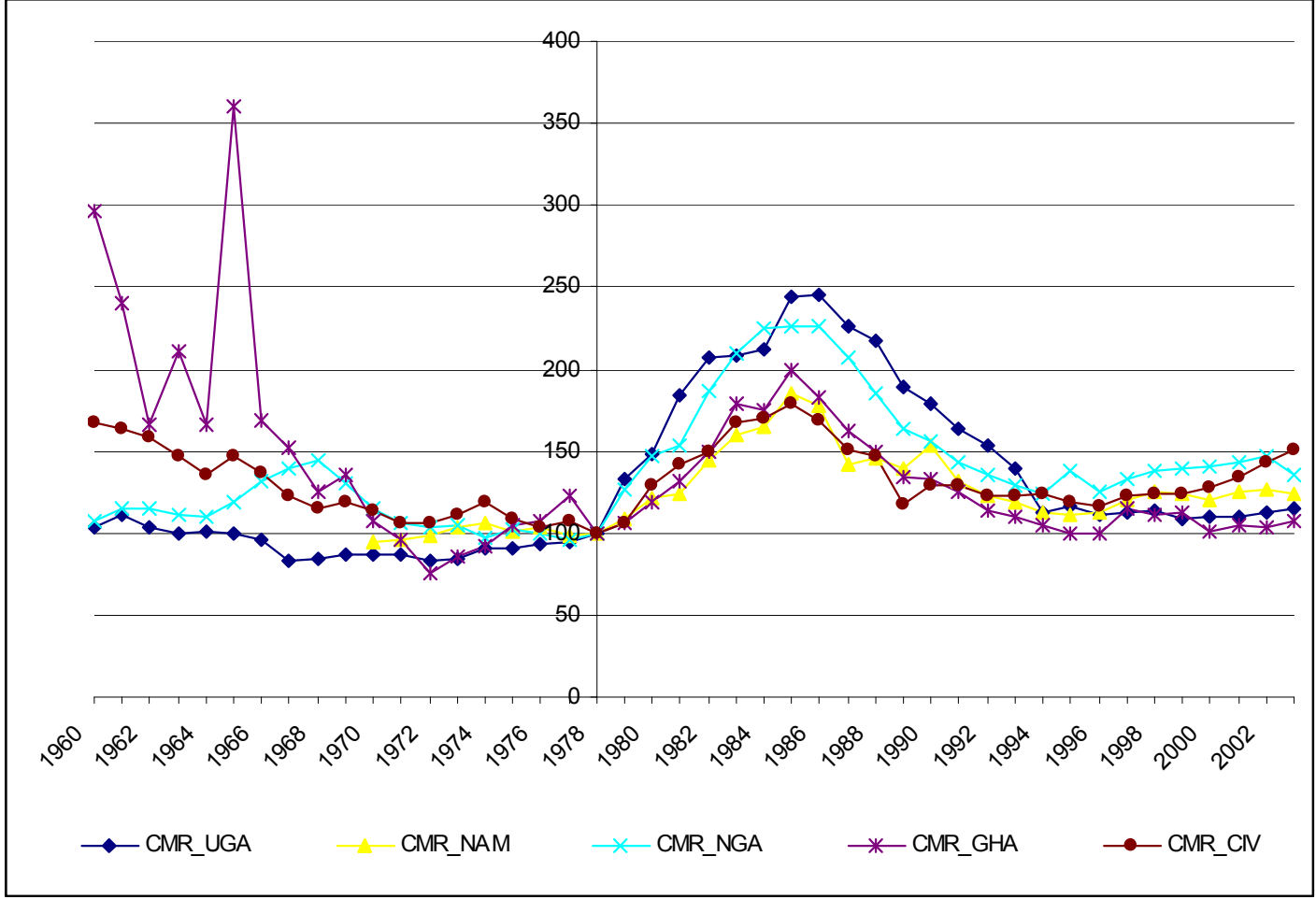

Figure 4: Cameroon with respect to the average of Uganda, Namibia, Nigeria, Ghana and Cote d'Ivoire Relative real GDP per capita (\$ in 2000 Constant Prices: Lasp.) 1978=100

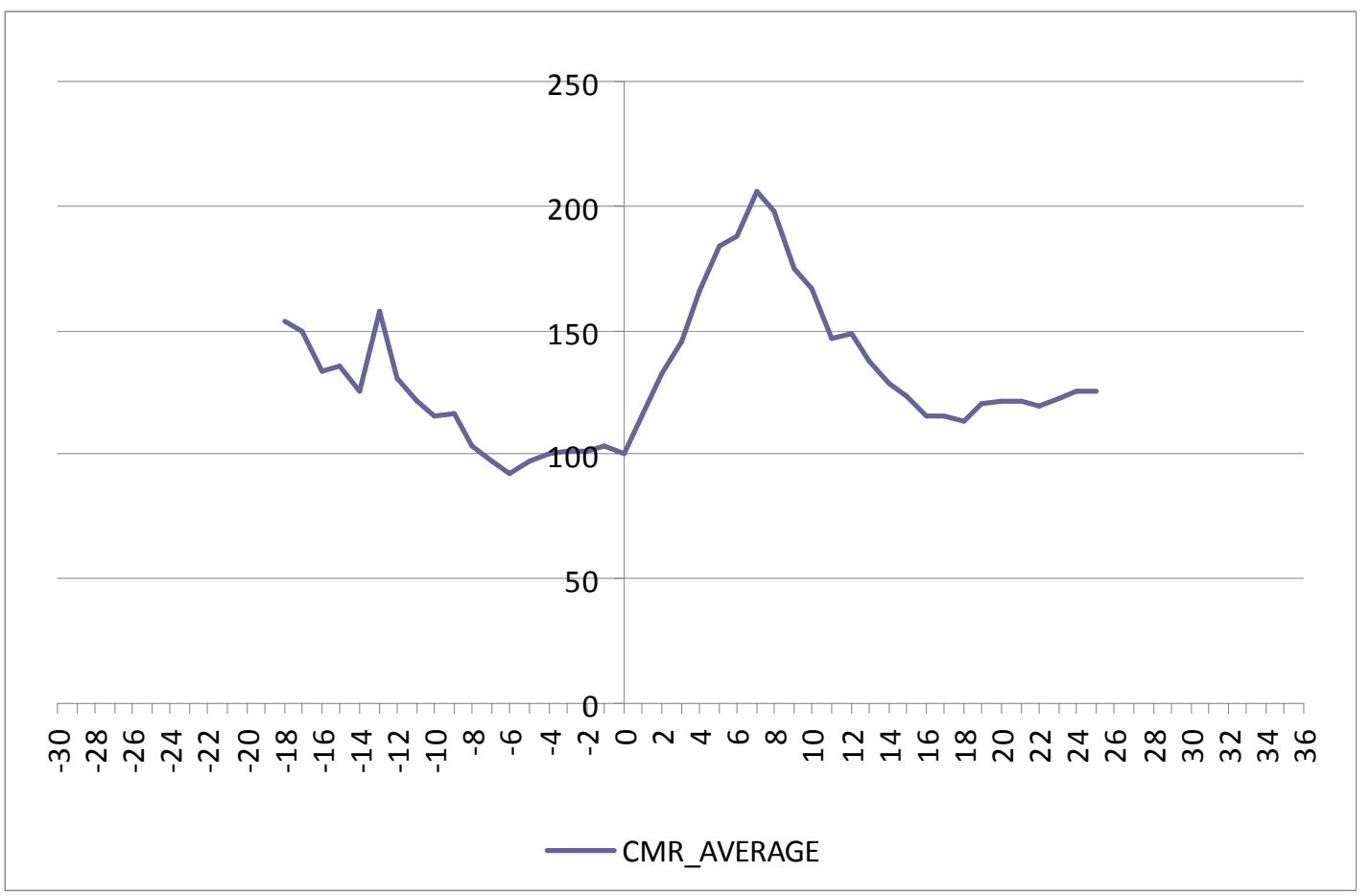


Figure 5: The Republic of Congo with respect to Namibia and Benin, 1962=100

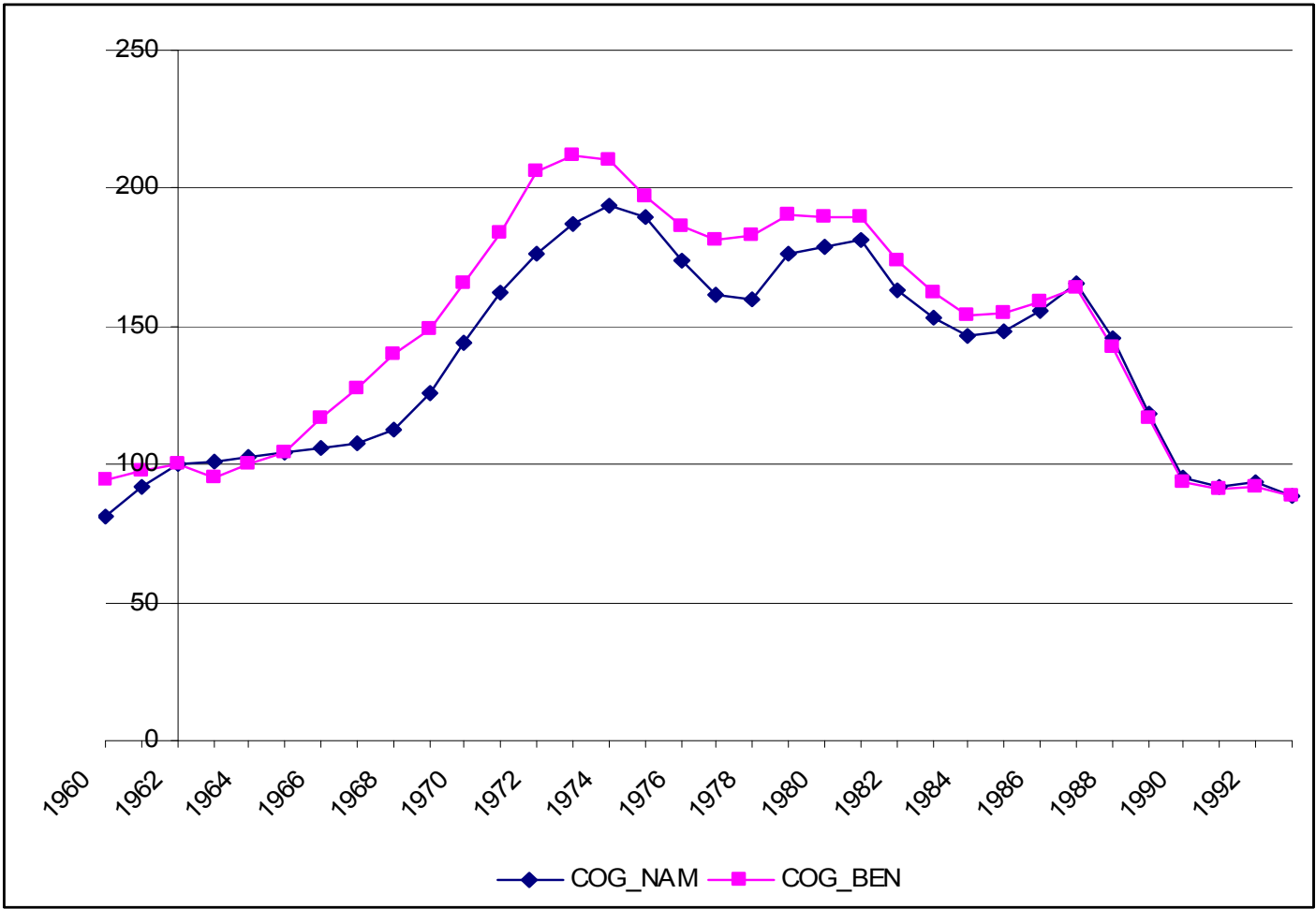

Figure 6: The Republic of Congo with respect to the average of Namibia and Benin, 1962=100

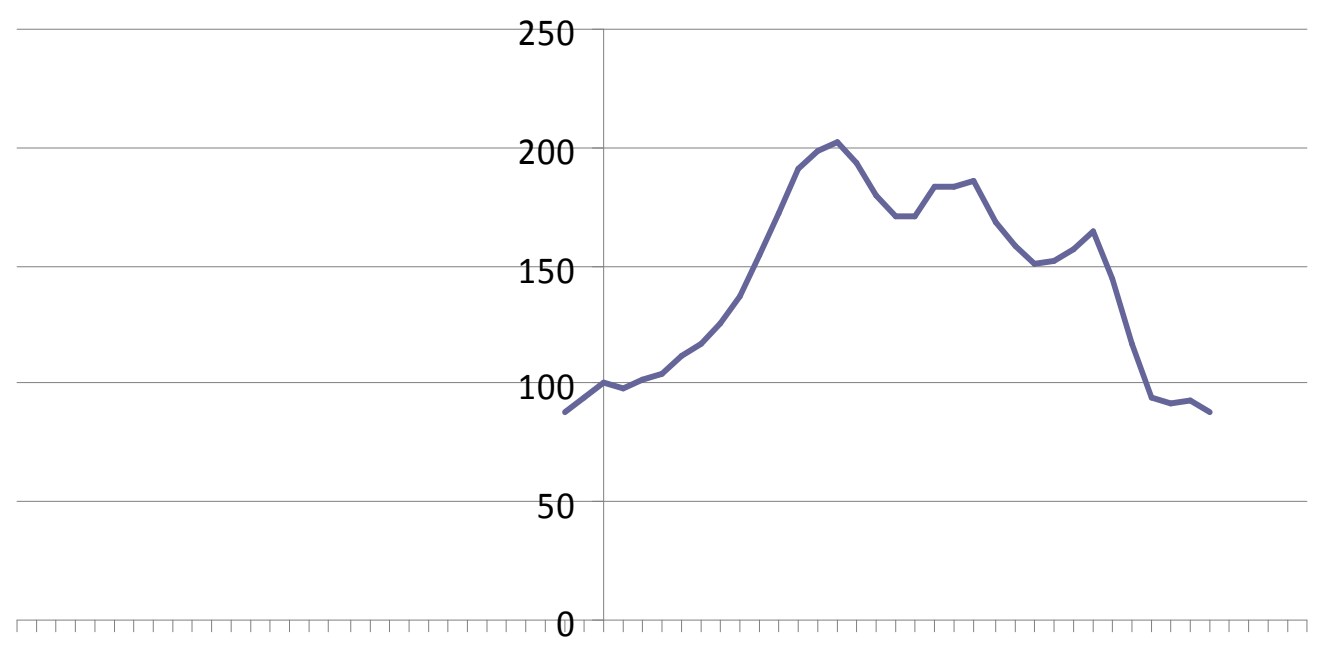

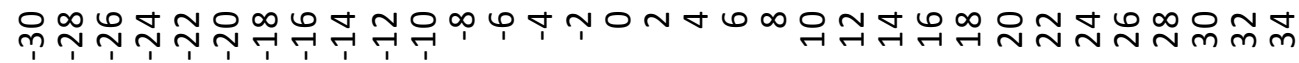

—COG_AVERAGE 
Figure 7: Ecuador with respect to Peru, Bolivia and El Salvador, 1972=100

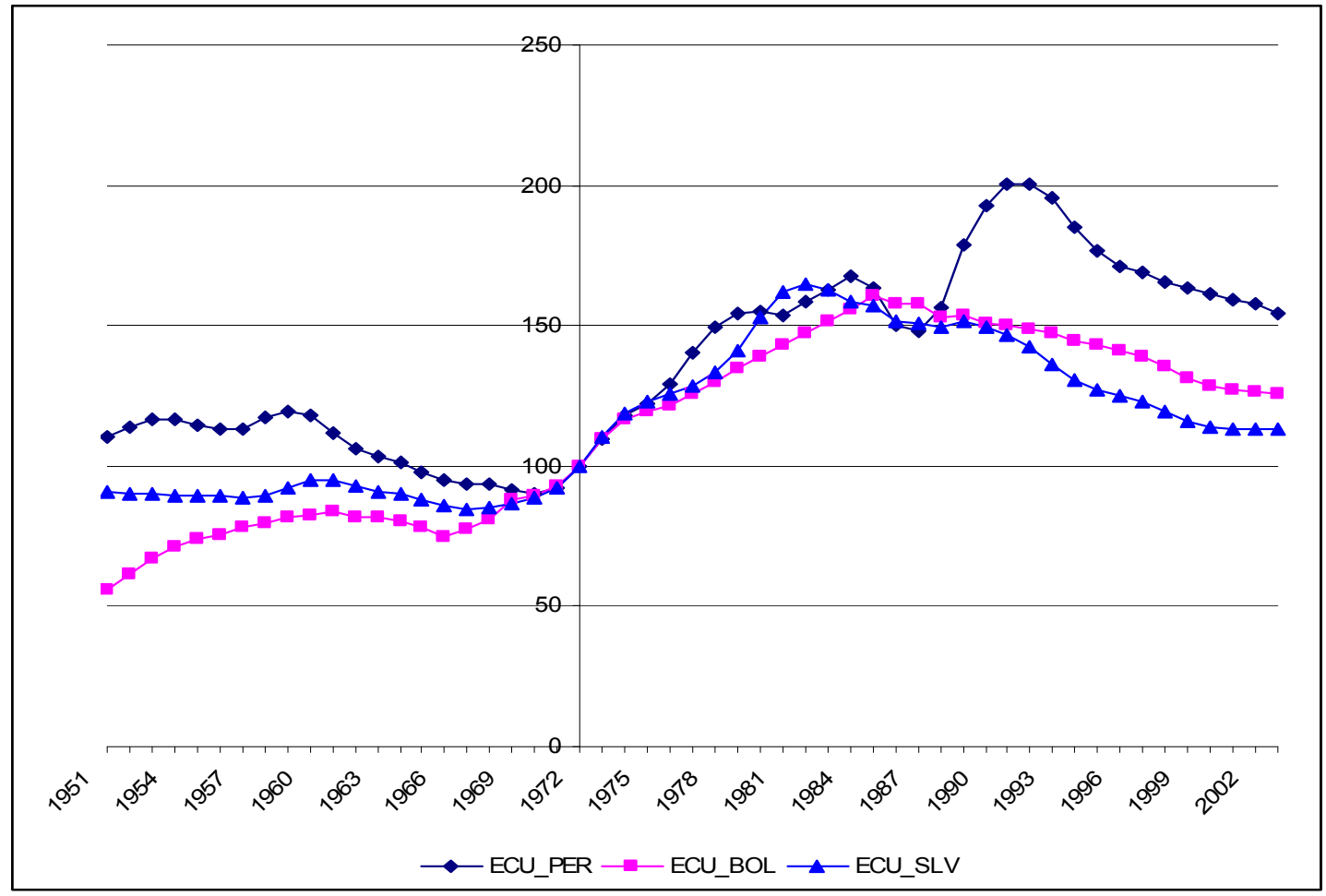

Figure 8: Ecuador with respect to the average of Peru, Bolivia and El Salvador, 1972=100

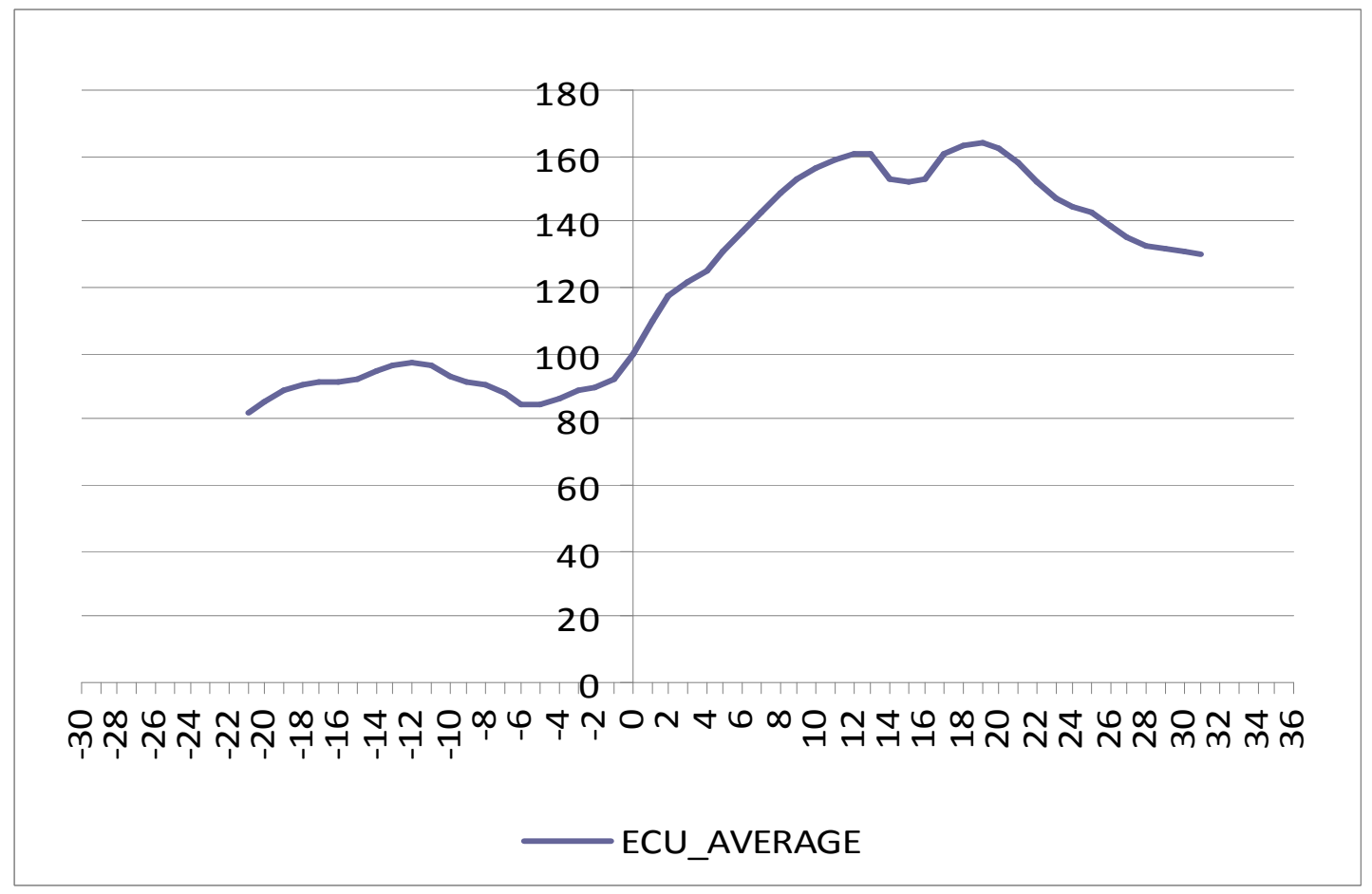


Figure 9: Egypt with respect to United Arab Emirates, 1978=100

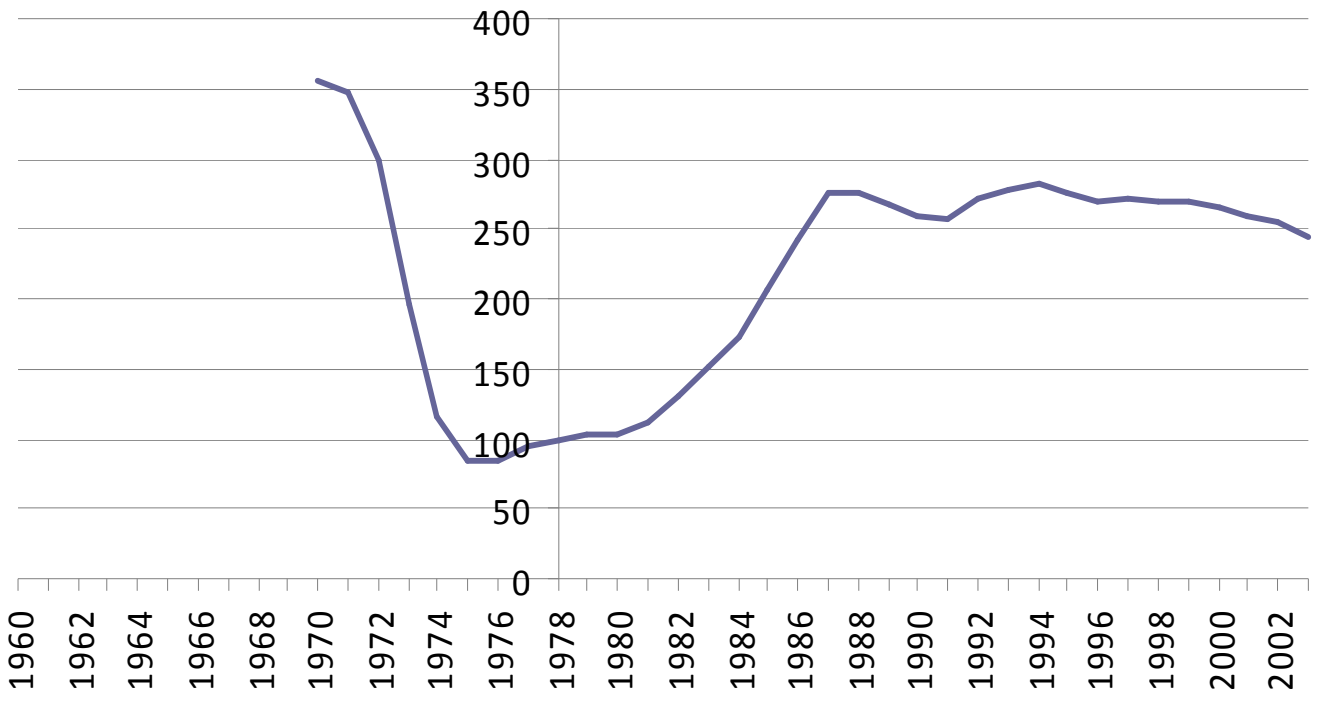

EGY_ARE 
Figure 10: Mexico with respect to Colombia and Nicaragua, 1980=100

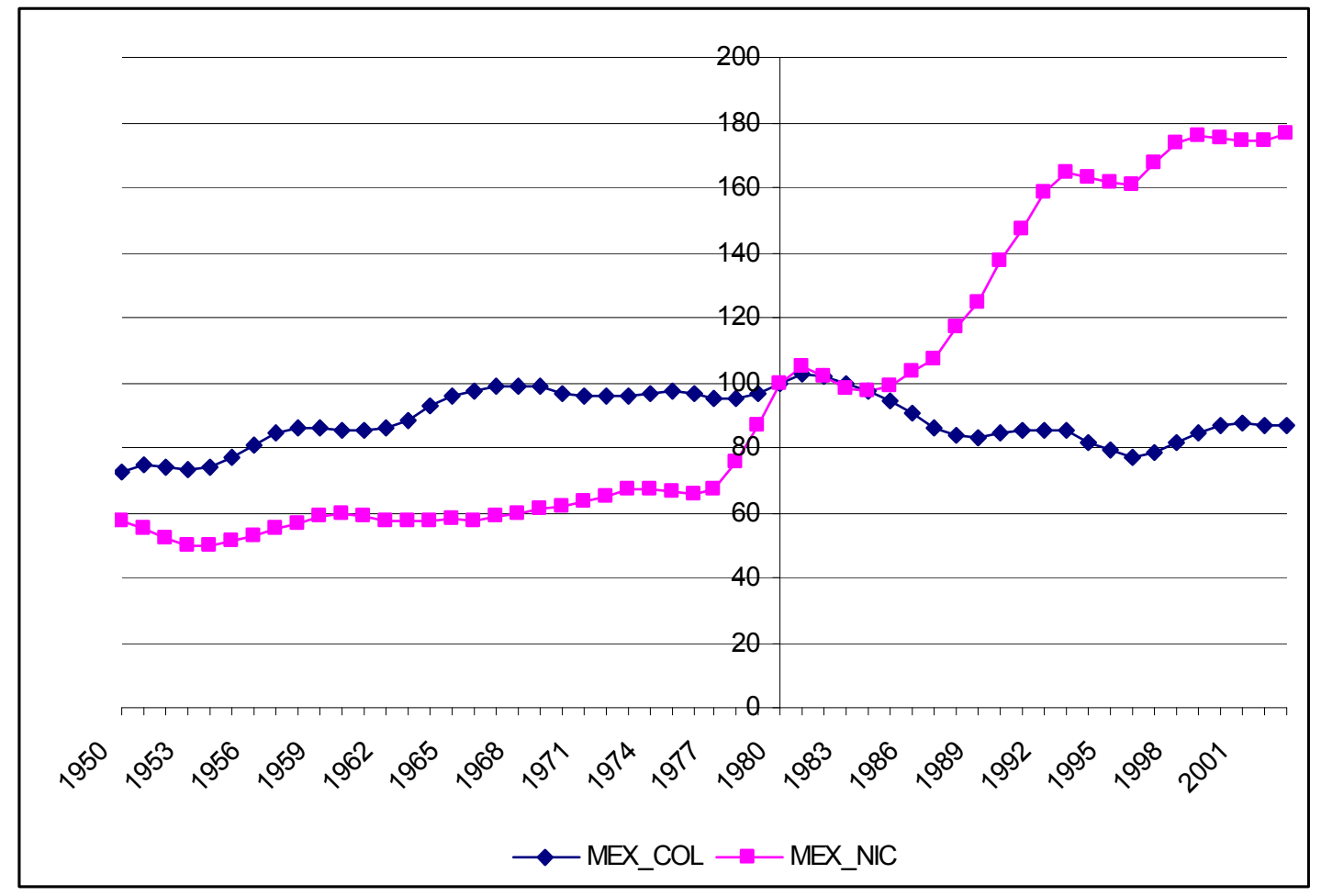

Figure 11: Mexico with respect to the average of Colombia and Nicaragua, 1980=100

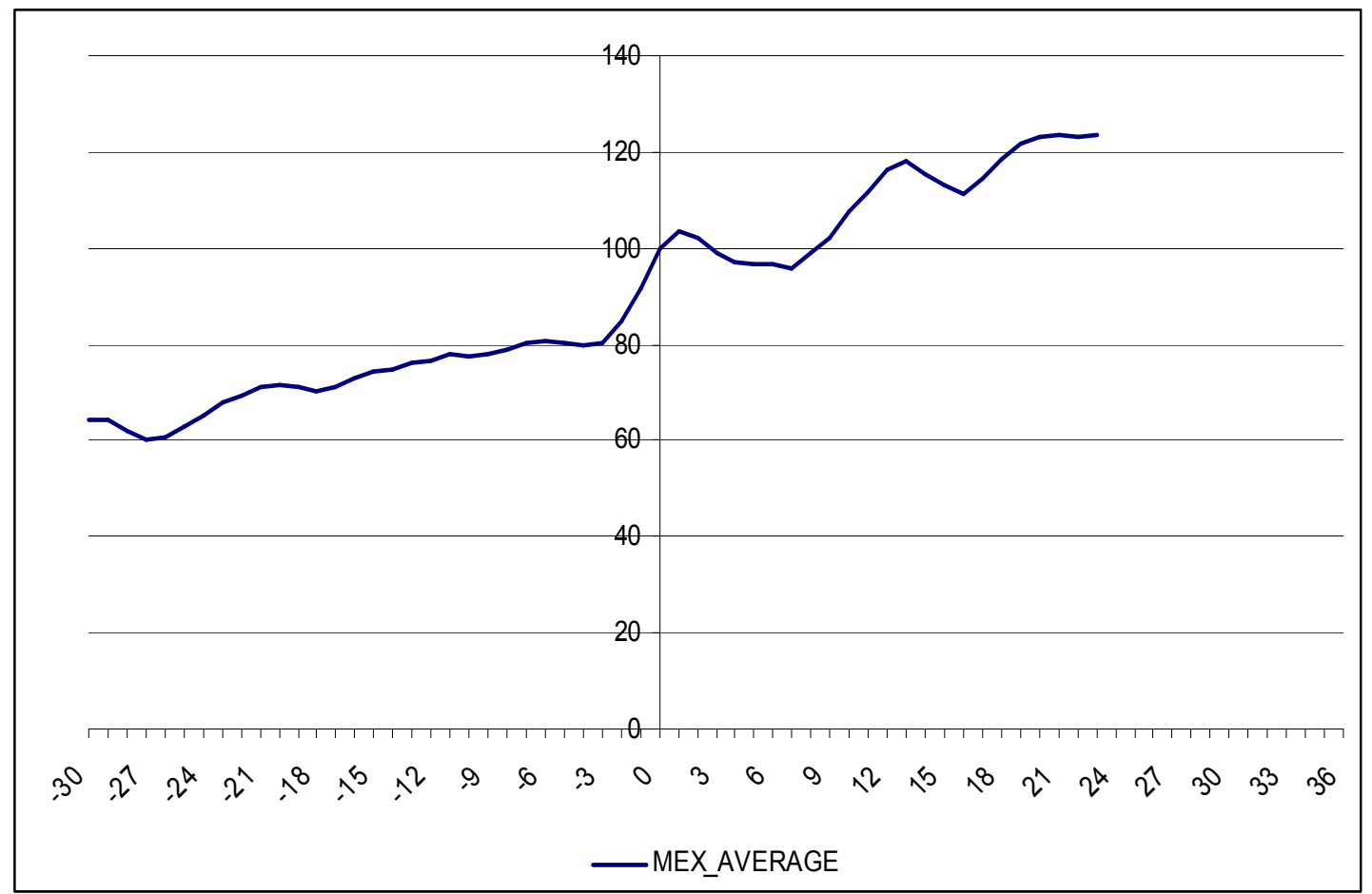


Figure 12: Morocco with respect to Bahrain and Tunisia, 1974=100

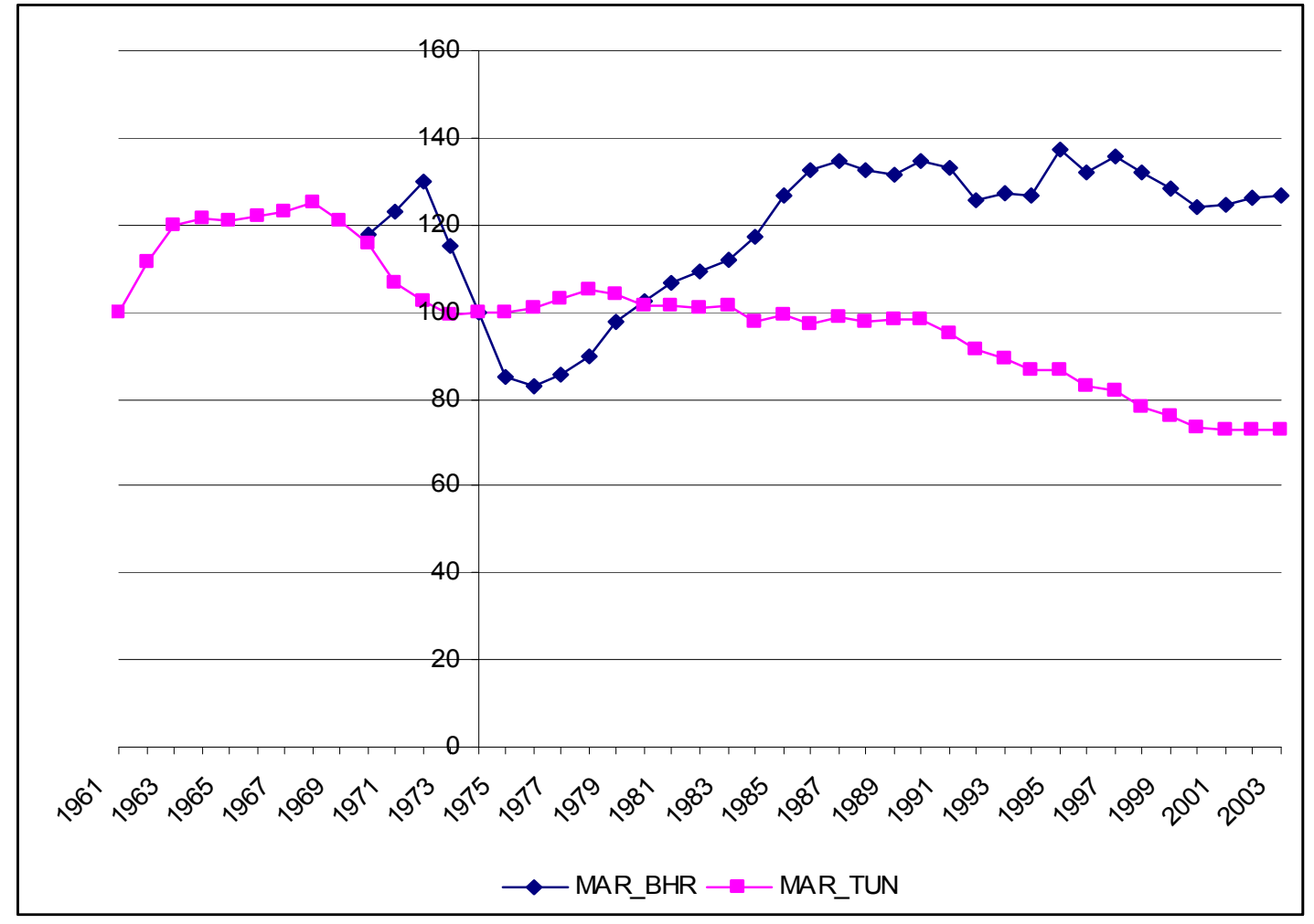

Figure 13: Morocco with respect to the average of Bahrain and Tunisia, 1974=100

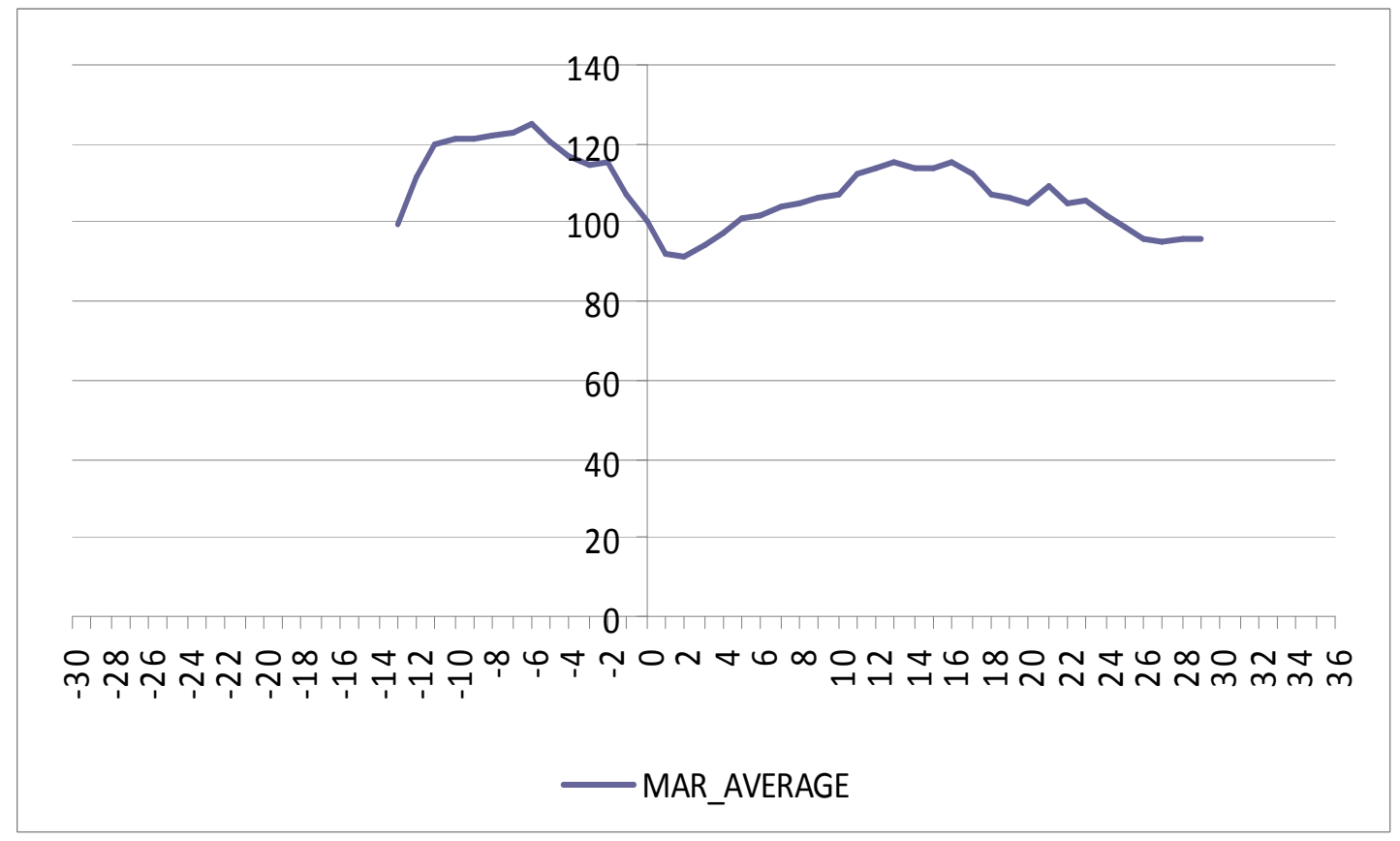


Figure 14: Niger with respect to Mali, Namibia, Sudan, Senegal, Sierra Leone and Tanzania, $1973=100$

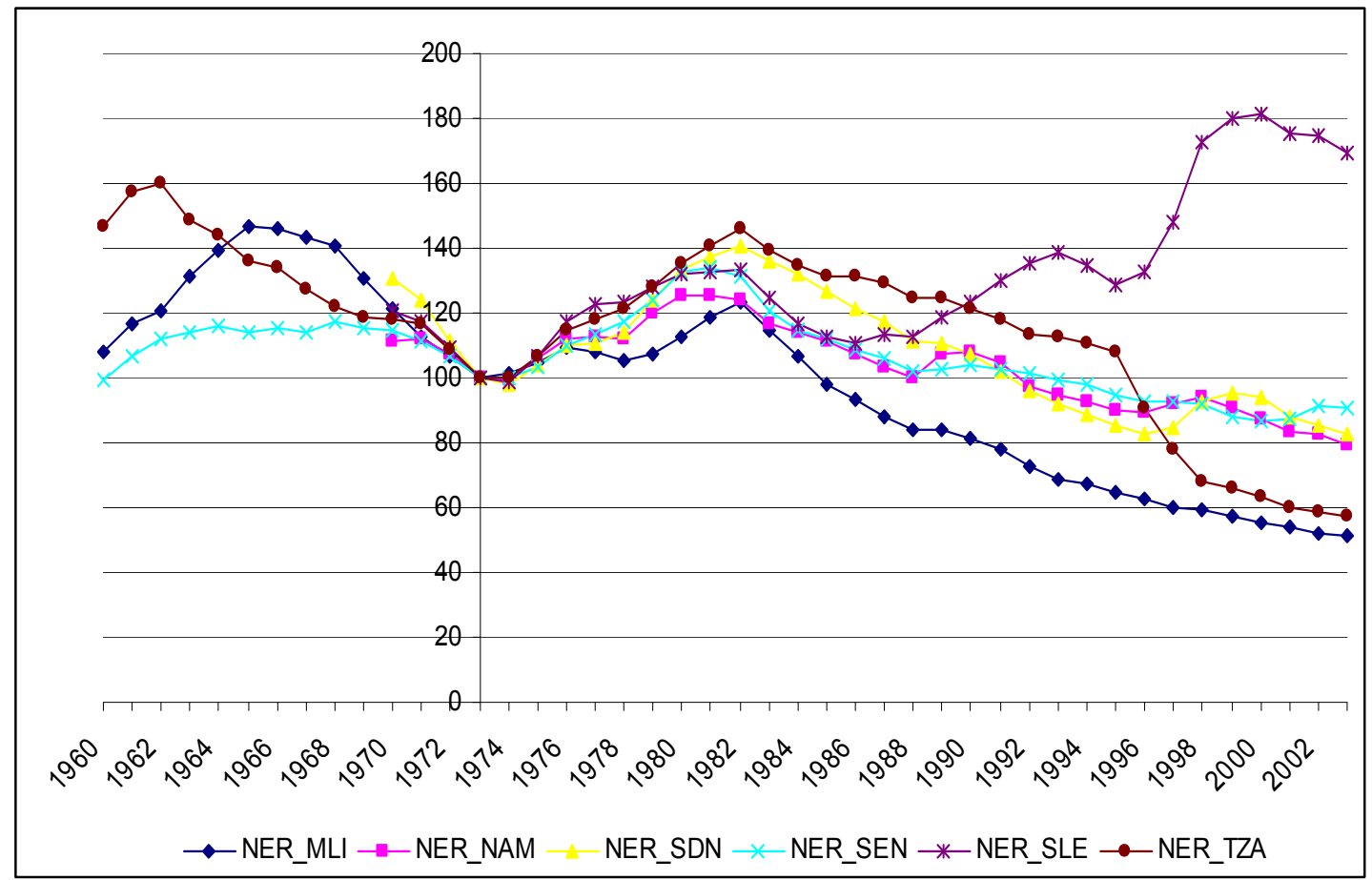

Figure 15: Niger with respect to the average of Mali, Namibia, Sudan, Senegal, Sierra Leone and Tanzania, $1973=100$

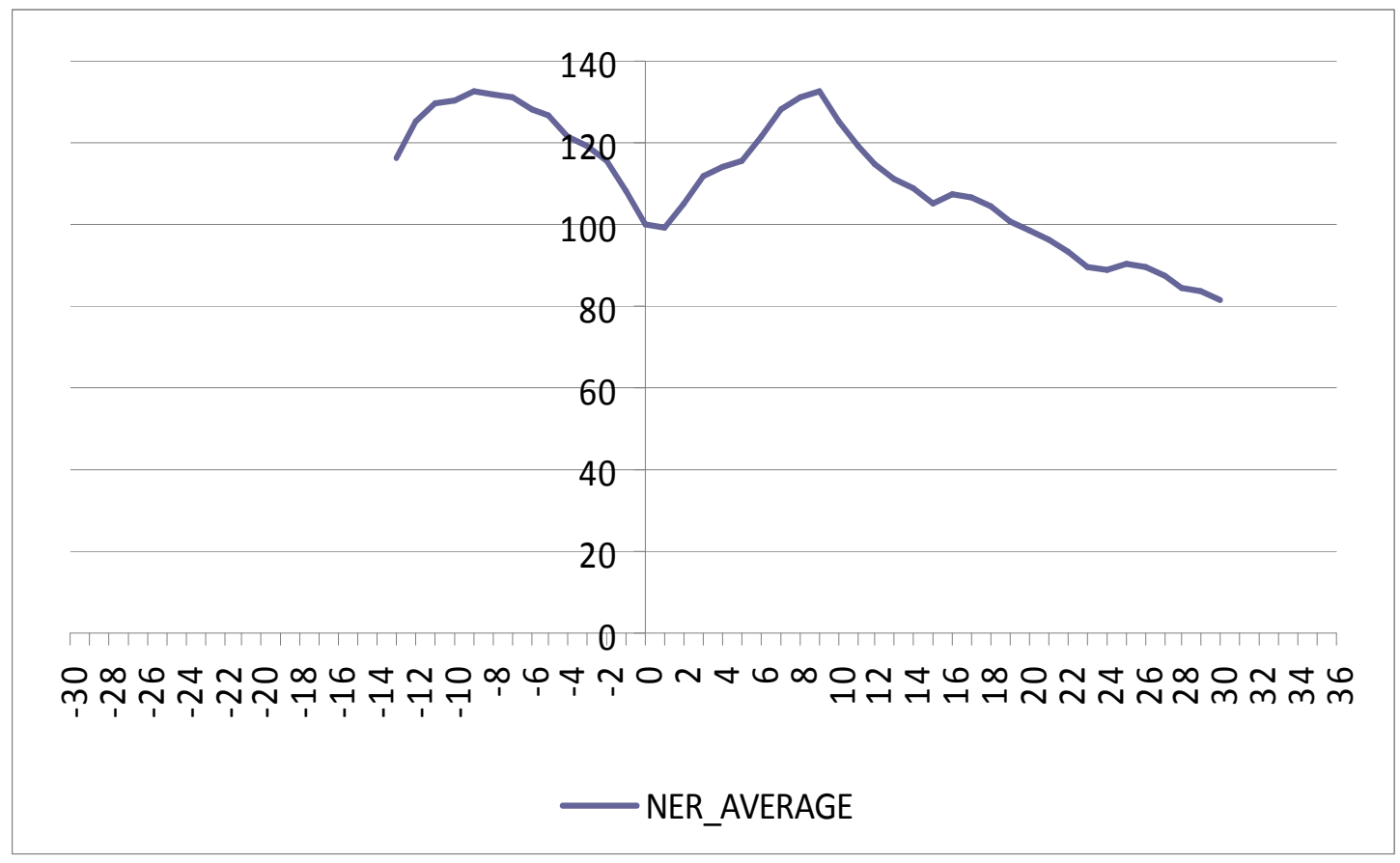


Figure 16: Nigeria with respect to Cote d'Ivoire, Guinea-Bissau, Ghana, Mali, Ethiopia, Burkina Faso, Kenya, Guinea and Uganda, 1968=100

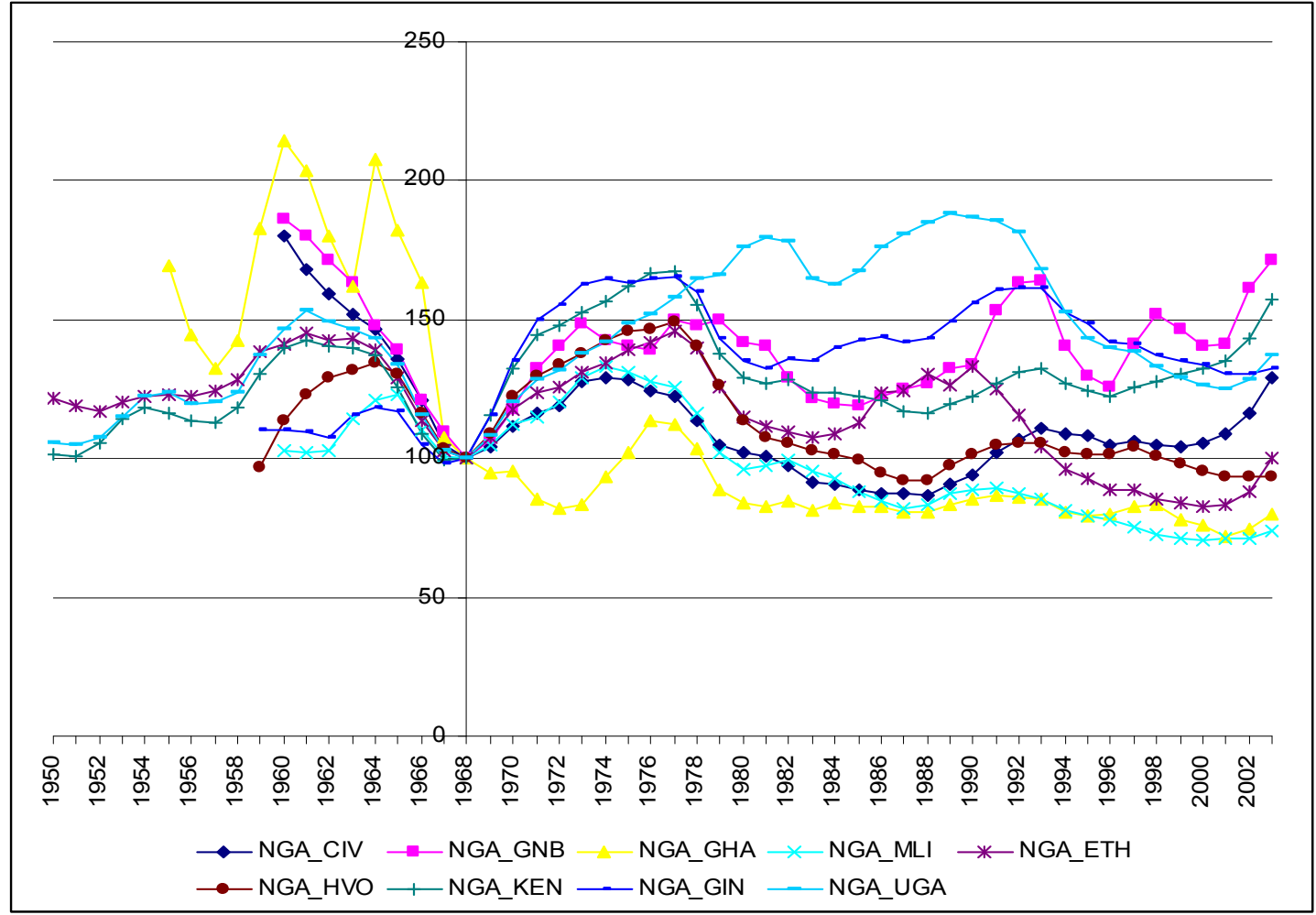

Figure 17: Nigeria with respect to the average of Cote d'Ivoire, Guinea-Bissau, Ghana, Mali, Ethiopia, Burkina, Faso, Kenya, Guinea and Uganda, 1968=100

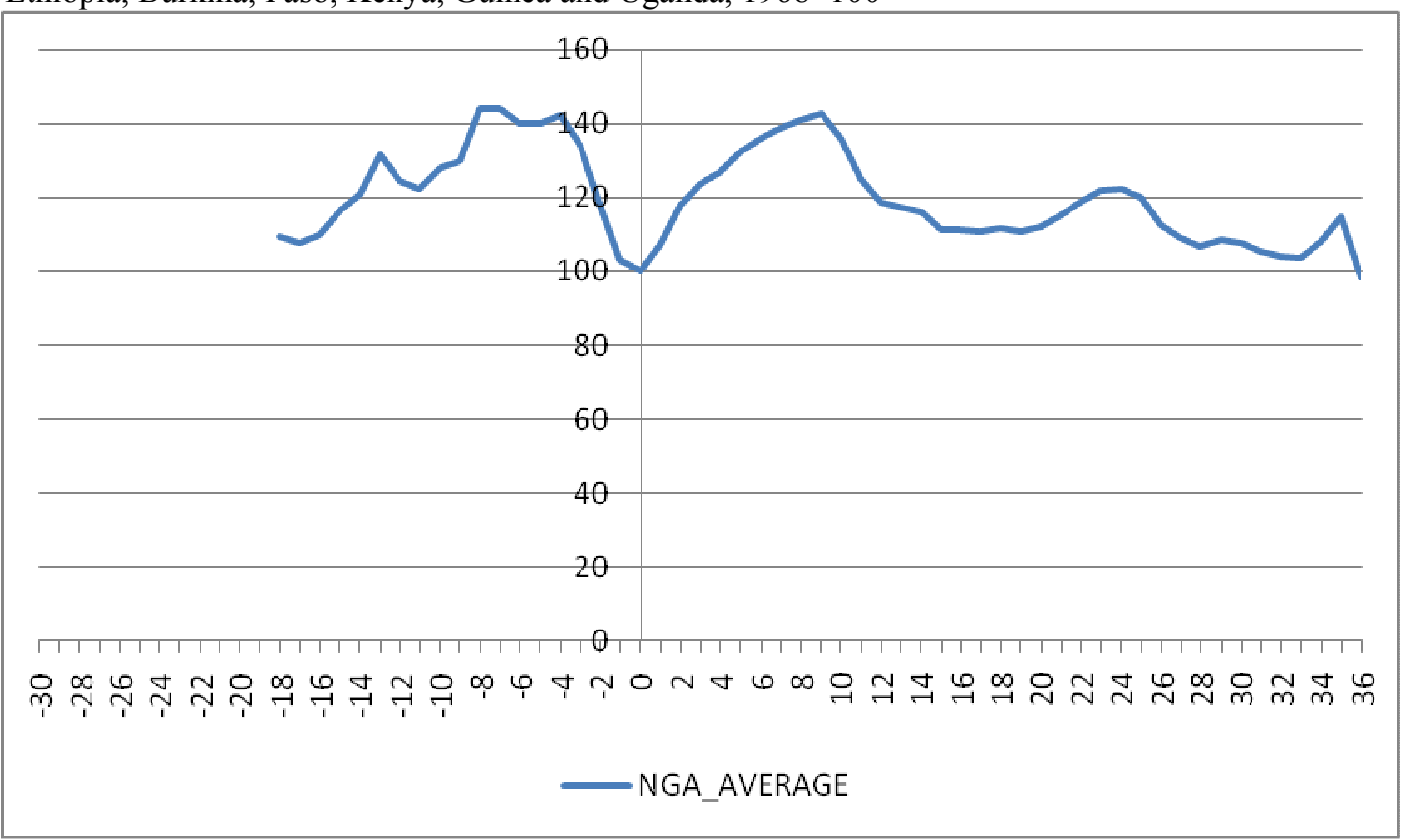


Figure 18: Norway with respect to Iceland, Austria, Denmark, Finland, France, Italy, Sweden, Ireland, Netherlands, Luxembourg, UK, USA, Spain, Greece, Belgium, Switzerland and Portugal, 1978=100

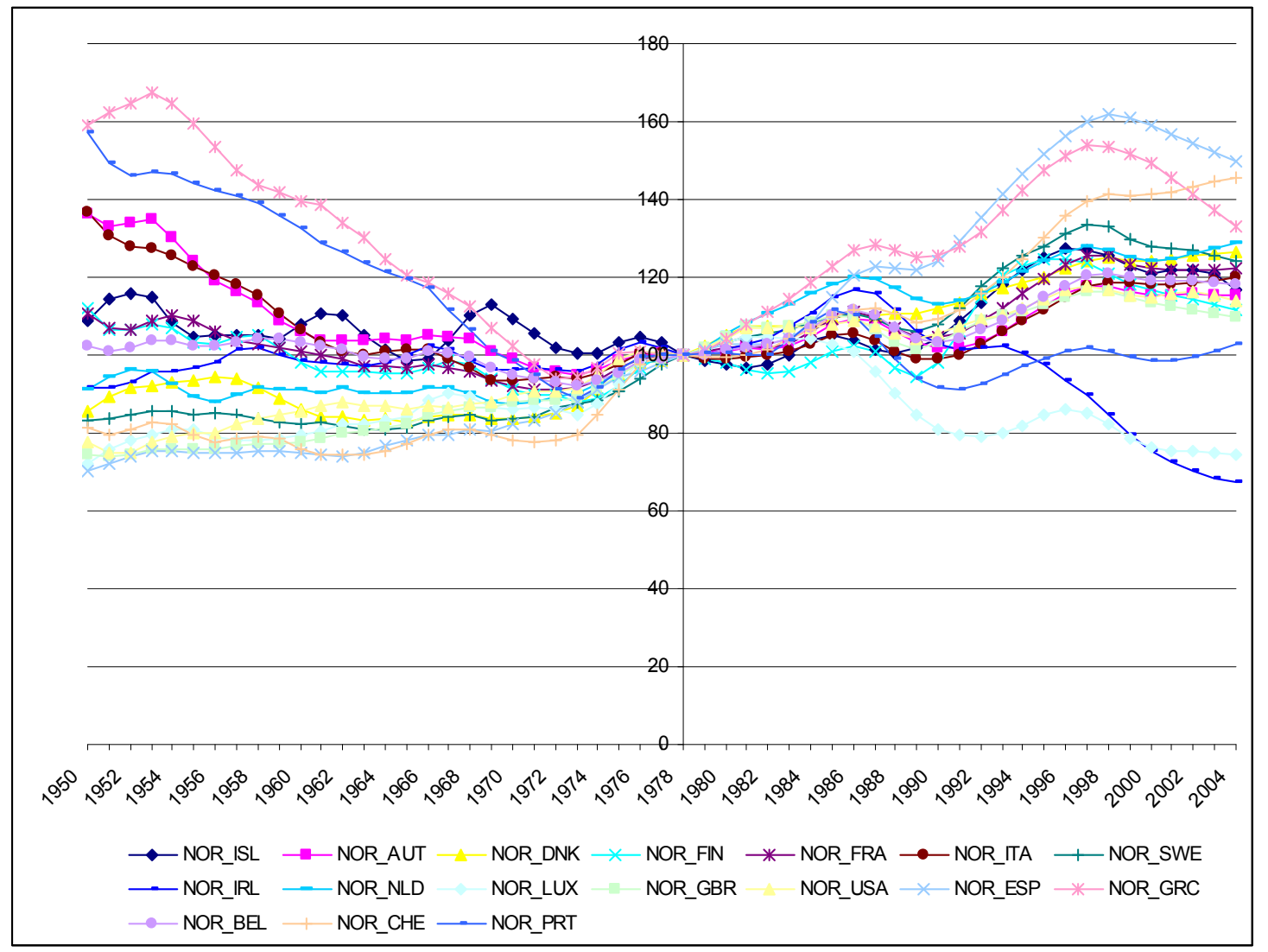

Figure 18: Norway with respect to the average Iceland, Austria, Denmark, Finland, France, Italy, Sweden, Ireland, Netherlands, Luxembourg, UK, USA, Spain, Greece, Belgium, Switzerland and Portugal, 1978=100

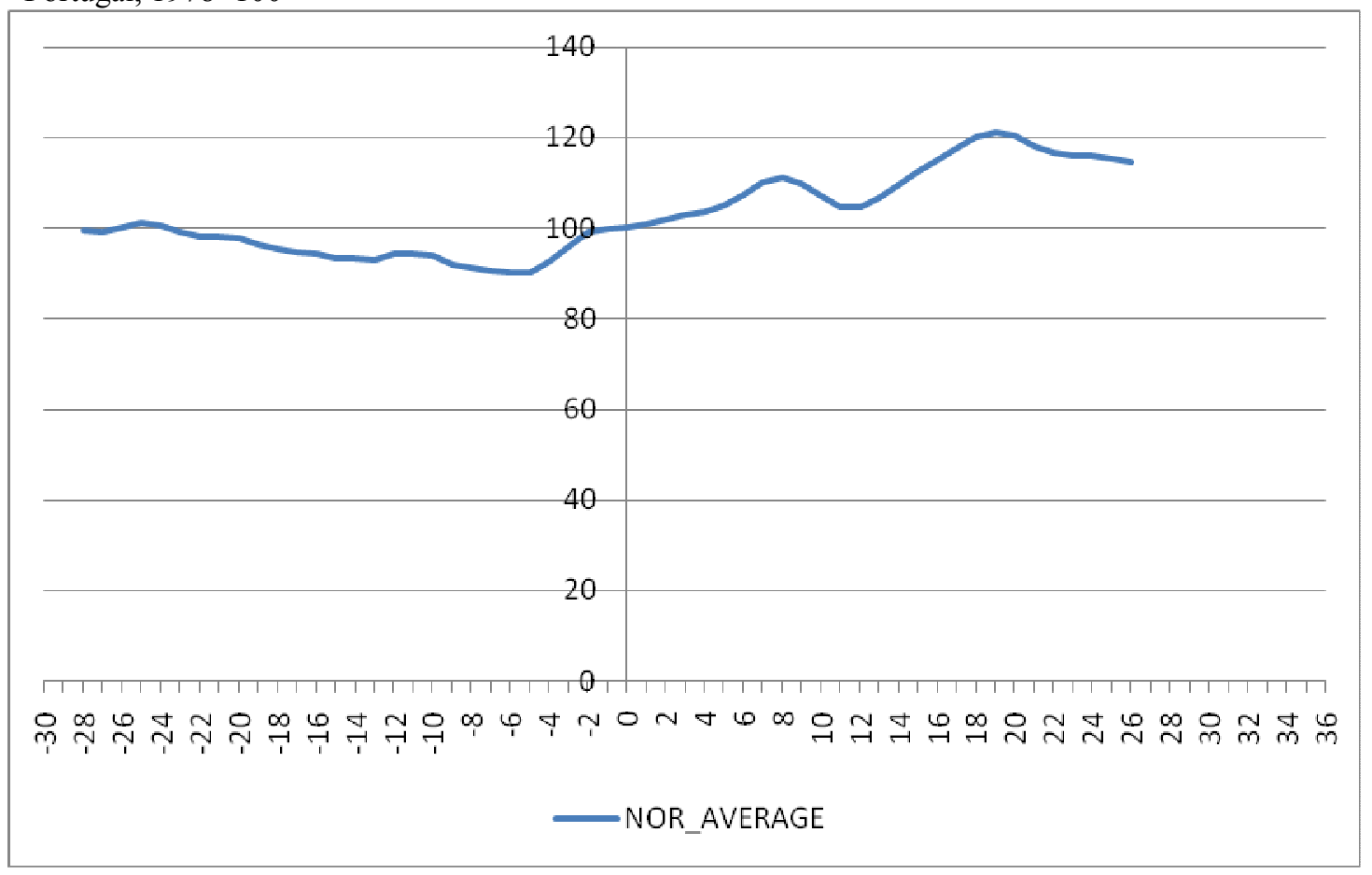


Figure 20: Senegal with respect to Sudan, $1980=100$

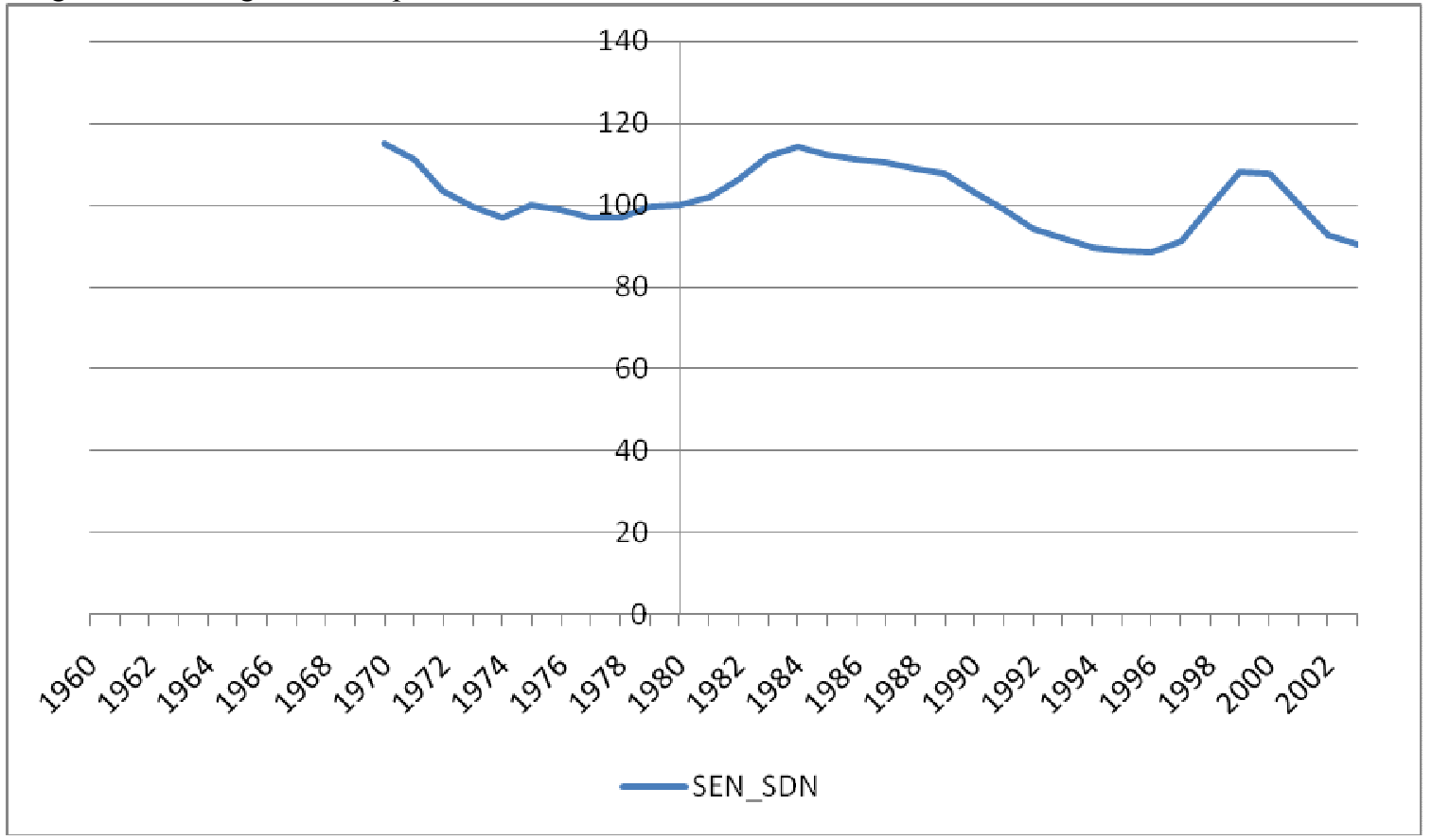


Figure 21: Togo with respect to Tanzania, Zambia, Malawi and Guinea-Bissau, 1982=100

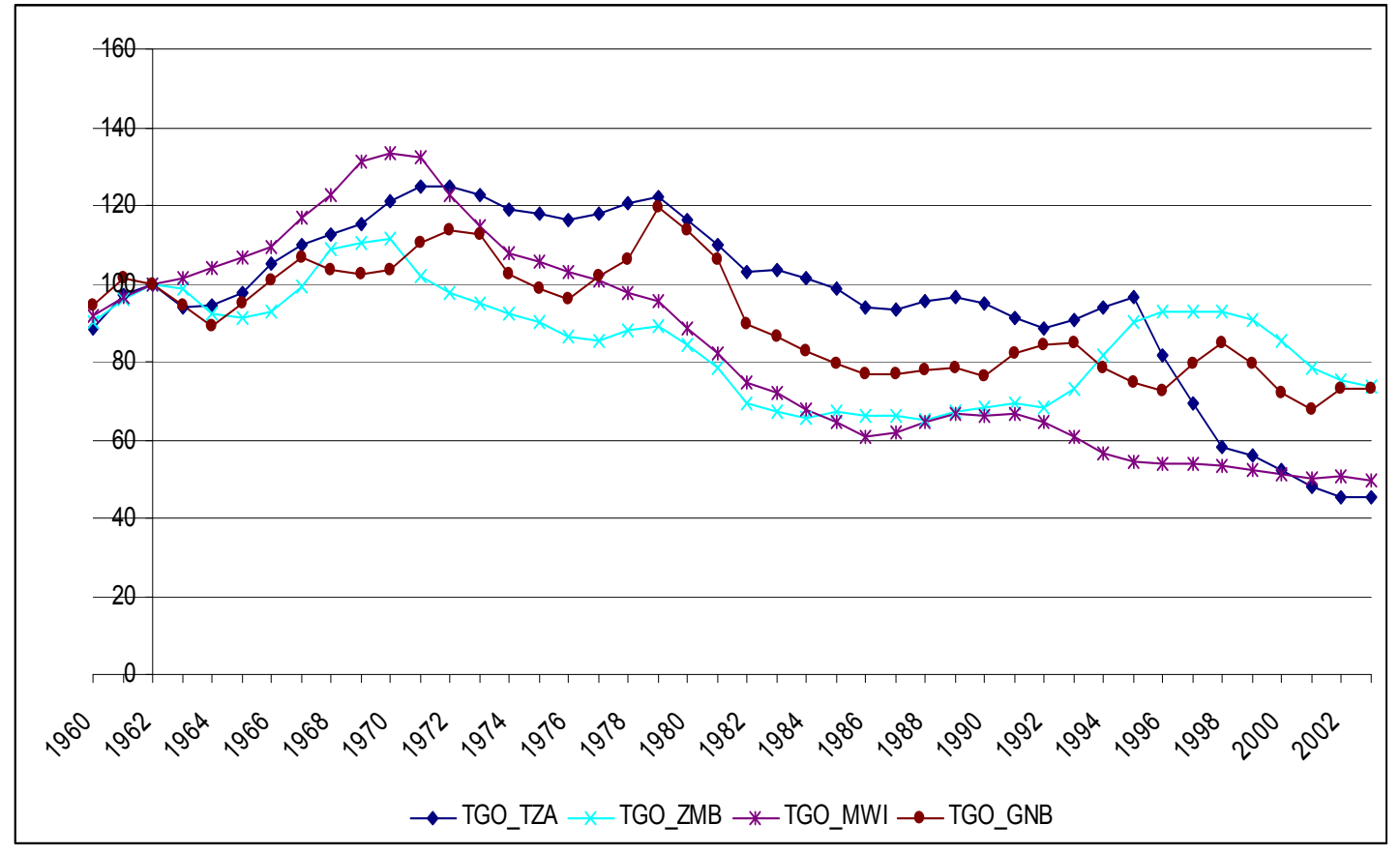

Figure 22: Togo with respect to the average of Tanzania, Zambia, Malawi and Guinea-Bissau, $1982=100$

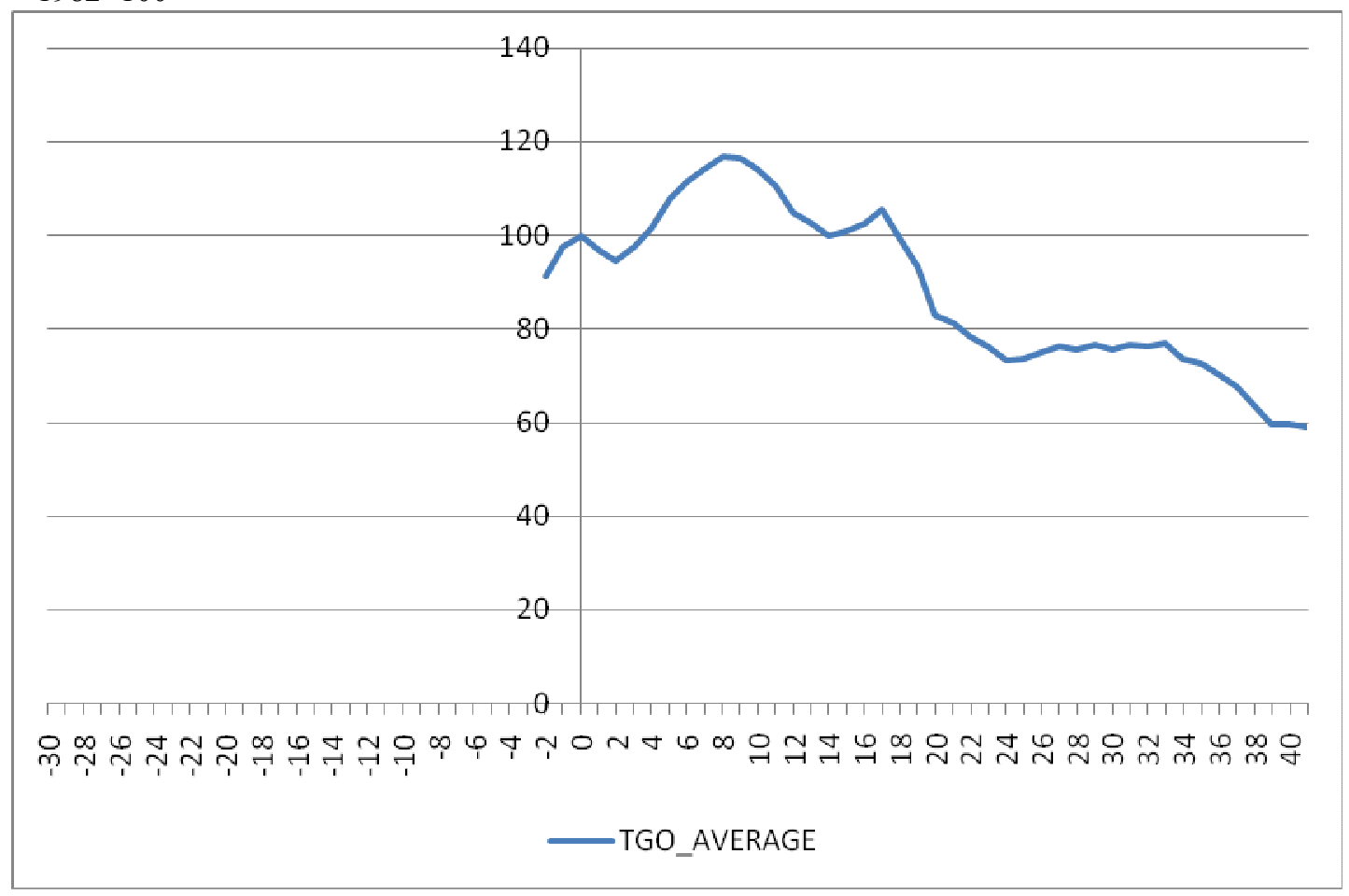


Figure 23: All countries average*, break date $=100$

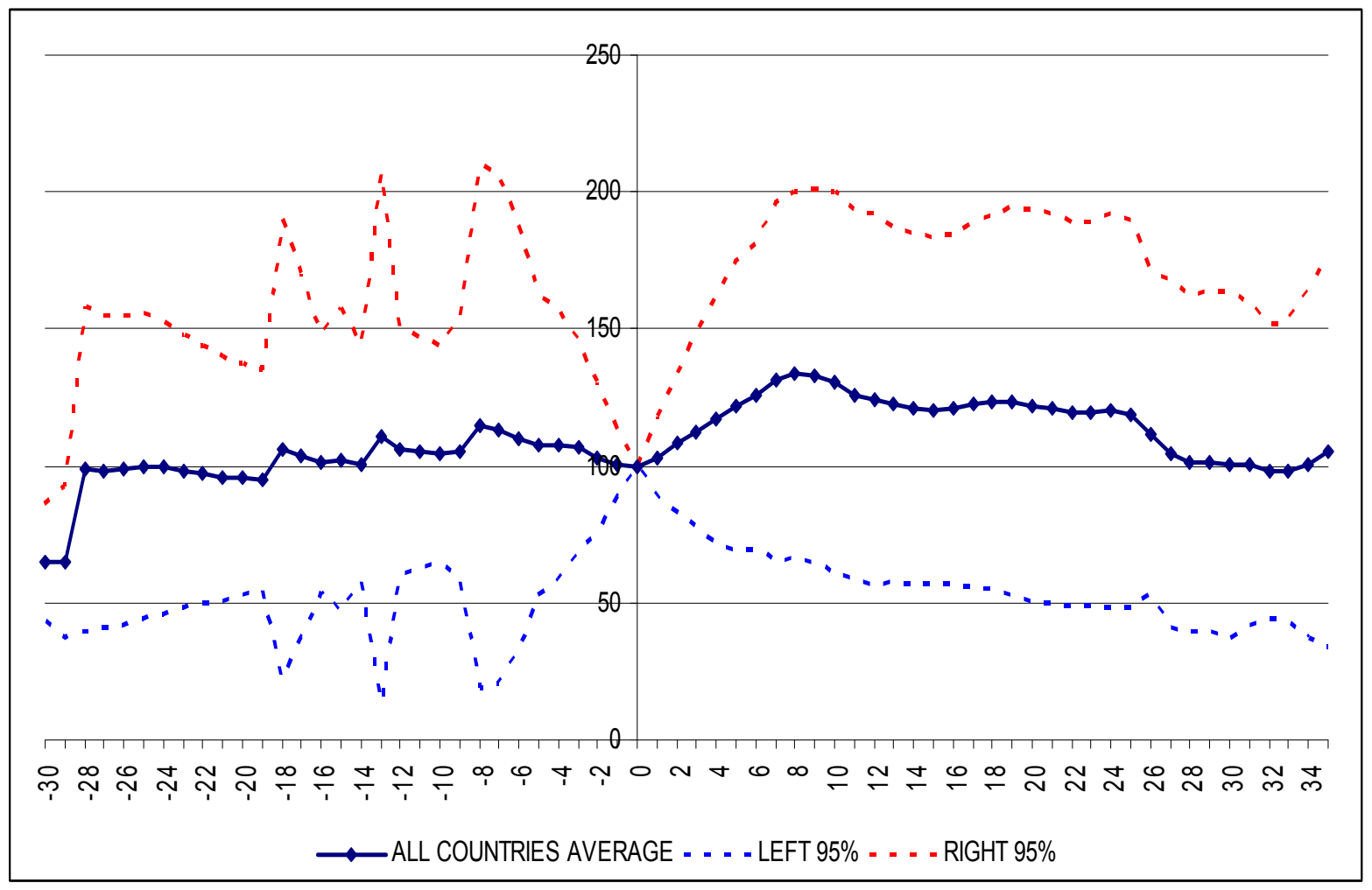

*excluding last 6 years for Togo 


\section{Working Paper Series}

ISSN 1211-3298

Registration No. (Ministry of Culture): E 19443

Individual researchers, as well as the on-line and printed versions of the CERGE-EI Working Papers (including their dissemination) were supported from the European Structural Fund (within the Operational Programme Prague Adaptability), the budget of the City of Prague, the Czech Republic's state budget and the following institutional grants:

- Center of Advanced Political Economy Research [Centrum pro pokročilá politickoekonomická studia], No. LC542, (2005-2011);

- Economic Aspects of EU and EMU Entry [Ekonomické aspekty vstupu do Evropské unie a Evropské měnové unie], No. AVOZ70850503, (2005-2011);

- Economic Impact of European Integration on the Czech Republic [Ekonomické dopady evropské integrace na ČR], No. MSM0021620846, (2005-2011);

Specific research support and/or other grants the researchers/publications benefited from are acknowledged at the beginning of the Paper.

(c) Ilkin Aliyev, 2011

All rights reserved. No part of this publication may be reproduced, stored in a retrieval system or transmitted in any form or by any means, electronic, mechanical or photocopying, recording, or otherwise without the prior permission of the publisher.

Published by

Charles University in Prague, Center for Economic Research and Graduate Education (CERGE) and

Economics Institute ASCR, v. v. i. (EI)

CERGE-EI, Politických vězňů 7, 11121 Prague 1, tel.: +420 224005 153, Czech Republic.

Printed by CERGE-EI, Prague

Subscription: CERGE-EI homepage: http://www.cerge-ei.cz

Phone: + 420224005153

Email: office@cerge-ei.cz

Web: http://www.cerge-ei.cz

Editor: Michal Kejak

Editorial board: Jan Kmenta, Randall Filer, Petr Zemčík

The paper is available online at http://www.cerge-ei.cz/publications/working_papers/.

ISBN 978-80-7343-254-6 (Univerzita Karlova. Centrum pro ekonomický výzkum a doktorské studium)

ISBN 978-80-7344-246-0 (Národohospodářský ústav AV ČR, v. v. i.) 
CERGE-EI

P.O.BOX 882

Politických vězňů 7

11121 Praha 1

Czech Republic http://www.cerge-ei.cz 